原

\title{
色彩色差計による口腔粘膜疾患の色彩測定に関する研究
}

\author{
山城 正 司 \\ 東京医科歯科大学歯学部口腔外科学第 1 講座（主任・指導：天笠光雄教授）
}

(1995 年 12 月 8 日 受付)

\section{A Study on Colorimetry of Oral Mucosal Lesions}

\author{
Masashi Yamashiro \\ The First Department of Oral and Maxillofacial Surgery, Faculty of Dentistry, \\ Tokyo Medical and Dental University \\ (Chief and Director : Prof. Teruo Amagasa)
}

Color observation is essential to diagnose oral mucosal lesions. In order to measure and record the color of the oral mucosa more objectively, colorimeters were evaluated. The noncontact-type colorimeter showed considered values comparable with those of visual color matching and was reliable.

The color distribution of the normal oral mucosa was from 5.0R to 4.1YR in hue, 3.5 to 6.0 in value, and 3.7 to 6.7 in chroma. The color distribution of leukoplakia was from 2.6RP to $3.4 \mathrm{YR}$ in hue, 3.7 to 7.0 in value, and 0.3 to 8.3 in chroma and the ranges thereof were considerably broader than those of normal mucosa and other mucosal lesions. The higher chroma of leukoplakia was, the severer epithelial dysplasia was.

The color distribution of oral cancer was from $3.0 \mathrm{R}$ to $8.2 \mathrm{YR}$ in hue, 2.7 to 6.4 in value, and 3.0 to 7.8 in chroma. The ranges of color distribution was broader than those of normal mucosa and narrower than those of leukoplakia.

The color distribution of lichen planus was from $1.7 \mathrm{R}$ to $8.9 \mathrm{R}$ in hue, 3.5 to 6.3 in value, and 3.6 to 8.5 in chroma. The chroma of erythema is the highest of all mucosal lesions.

Some oral mucosal lesions are suggested to have characteristic colors.

\section{I. 緒言}

口腔粘膜の白板症は前癌病変とされており, び らんや紅斑を伴ったものが，悪性化しやすいとい われている11。口腔粘膜癌は多彩な臨床像を呈す るが, 初期の癌は潰瘍も硬結も伴わないものが多 く, 前癌病変の白板症や紅板症, あるいは乳頭腫 に類似しており，鑑別診断が困難なことも少なく ない2)。これら口腔病変の臨床診断にあたり, 色彩
の変化，表面の形態，硬さなどの視診，触診所見 はきわめて重要であると考えられる。

これまで, 口腔粘膜癌などの色彩を科学的に記 録したものとしては藤井の報告のみである ${ }^{3)}$ 。藤 井は標準色票 (口腔粘膜比色スケール) を試作し, 視感比色法を用いて, 口腔粘膜疾患の色彩を表示 し，診断に応用してきた。このような標準色票と の比較による色彩表示方法は, 直感的にわかりや すく, 照明環境を一定にし, 同時並列比較で行え 
ば精度も高いが，色票による色の比較は視感によ るものであり，検者の個人差，熟練度，心理的状 態などに左右されることは避けられないとされて いる4)。また，粘膜の色彩は中間的な色が多く微妙 な色の差があり，多くの色票を準備しても，対象 と全く合致した色票はあり得ず，補間による色彩 の判定を行っているのが現状である。また，口腔 粘膜比色スケールの色票は紙に顔料を塗布してつ くられたものであり，粘膜と質が異なるため両者 を客観的に比較するという点にも，視感比色法の 適応の困難さがあると考えられる。そこで著者は, これら困難を克服し，さらに客観的，定量的な評 価を行うために視感を用いない，色彩計による色 彩の計測を試みることとした。色彩計を選定，比 較検討し, 計測方法, および精度・再現性につい て検討を行い, 健常口腔粘膜, 各種口腔粘膜疾患 の色彩を測定, 比較し, 色彩計測による診断の可 能性を検討した。

\section{II. 研 究 対象}

\section{1. 予備的実験による症例}

予備的測色実験のために, 健常成人 4 名を対象 とし, 上顎前歯部の唇側付着歯肉, 舌側縁, 頓粘 膜，下唇を測色した。

\section{2. 健常口腔粘膜}

全身疾患および口腔粘膜疾患を認めない 20 30 歳代の健常成人 35 名 (男性 23 名, 女性 12 名）を対象とし, 下唇, 上顎前歯部の唇側付着歯 肉，舌側縁，頓粘膜を測色した。

\section{3. 口腔粘膜疾患}

白板症 57 名 (男性 36 名, 女性 21 名, 平均 58.5 歳), 扁平上皮癌 62 名 (男性 26 名, 女性 36 名, 平均 64.0 歳), 扁平苔癬 13 名 (男性 2 名, 女性 11 名, 平均 54.8 歳), 色素沈着症 6 名（男性 1 名, 女性 5 名, 平均 50.0 歳), 悪性黒色腫 2 名 (女性 2 名, 平均 56.0 歳) を口腔粘膜疾患の対象例とし た。

\section{III. 研 究方法}

\section{1。使用する表色系}

1) マンセル表色系 (JIS Z 8721)

色彩の表示は JIS Z 8721（三属性による色の表 示方法）に準拠し，マンセル表色系を用いた。色 相, 明度, 彩度の三要素は色の三属性と呼ばれ, 色相を外周，明度を縦軸，彩度を中心からの横軸 とした三次元立体として考えることができる。マ ンセル表色系は，これら 3 つの座標軸上で知覚的 に等歩度になるように目盛りを定めたものであ る ${ }^{5)}$ 。JIS の標準色票や医学用標準色票である皮膚 色票, 口腔粘膜比色スケール などは, この表色系 に基づいてつくられており，值から色をイメージ しやすく，こうした色票を併用し提示することに よって，大まかに色を伝えることができる。

2) L*a*b*表色系 (JIS Z 8730)

色差の表示は JIS Z 8730 （色差表示方法）に準 拠し， L*a*b*表色系を用いた。 $L^{*} a^{*} b^{*}$ 表色系は CIE (国際照明委員会) が 1976 年に定めた均等色 空間の一つ，すなわち色差の量を表すのに都合よ くつくられた色の座標系である ${ }^{6)}$ 。 $\mathrm{L}^{*}$ は明度, $\mathrm{a}^{*}$, $\mathrm{b}$ *は色相と彩度を示す色度（クロマティクネス指 数）を表す。

本研究では視感比色值と比較し, 測定值の妥当 性を検討するためにマンセル表色系を，またマン セル表色系では表現し得ない色差を検討するため に L*a*b*表色系を用いた。なお，各種表色系への 変換は Color Land 社製（元吞昭夫氏提供）の Colorimetric Calculation System I を使用した。

\section{2. 色彩の測定方法}

1）視感比色法による測定方法

体系づけられた色のスケールと試料とを視感に よって比較し，色を測定する方法である。JIS Z 8723 (表面色の比較方法) に基づき, 試料と口腔 粘膜比色スケール ${ }^{3)}$ との肉眼による直接比色法に て行った。比色時に用いる光源は，人工太陽照明 灯 SOLAX XC-100（色温度 $5500 \mathrm{~K}$ ：セリック株 式会社製)を使用し，1,000ルクス以上の照度にて 測定を行った。 
2 ）接触型色彩計による測定方法

接触型色彩計としては，SM カラーコンピュー 夕- $\mathrm{SM}-5-\mathrm{FCH}$ (計測部 SM-5 型, 光学部 $\mathrm{FCH}$ 型：スガ試験機株式会社製；図 1) を用い, ファ イバー先端部を被検部にフェザータッチで密着さ せて測定した。

3 ）非接触型色彩計による測定方法

非接触型色彩計としては, 色彩色差計 CS100 （ミノルタカメラ(㮫製：図 2 a) を用い, 人工 太陽照明灯 SOLAX-100により被検部を 45 度の 角度から照明し, 垂直方向から測定した(図 2 b)。

\section{3. 色彩計の測定精度の比較}

1) 色票の測色結果の比較

接触型色彩計と非接触型色彩計を用いて，色彩 の明らかな 3 種類の色票を上記測定法にて行っ た。

\section{2 ）口腔粘膜の測色結果の比較}

接触型色彩計，非接触型色彩計を用いて，健常 成人 2 名の上顎前歯部の唇側付着歯肉および舌側 縁の色彩測定を上記測定法にて行い，視感比色法 による結果との比較検討を行った。

\section{4. 非接触型色彩計による測定方法の検討}

前記 3.で比較したところ, 非接触型色彩計が視 感比色法に近似し，肉眼所見とも一致したため, 本色彩計による測定方法を検討した。

\section{1 ) 測定条件の検討}

照明，光源距離および測定距離等の測定条件を 変え, 色票を測定した。標準光源には人工太陽照 明灯 SOLAX XC-100 を使用し, 室内照明灯, デ ンタルチェアー備え付けのデンタルライトを使用 した場合についても検討した。臨床上の測定状況 を考慮し, 光源距離は $0.5 \sim 1 \mathrm{~m}$, クローズアップ レンズ No.122（測定径 3.2〜 4.3 mm）を装着し, 測定距離 323 368 mm の可動範囲内にて測定を 行った。

\section{2 ）口腔粘膜測色法}

口腔粘膜色の測定にあたり，前記 1） と同様の 測定条件下に測色を行った。なお口腔内における 任意基準校正を正しく行うために，デンタルミ ラ一型標準白色板（図３）を試作した。このデン

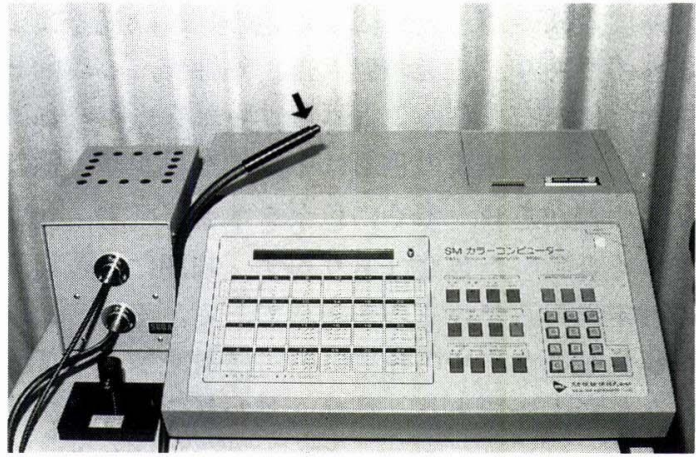

図 1 接触型色彩計, $\mathrm{SM}$ カラーコンピューターSM5- FCH (計測部：SM-5 型, 光学部： FCH 型) ( 又 ガ試験機(㑣)製)。：ファイバー先端部(被検部に 密着させて測定する)

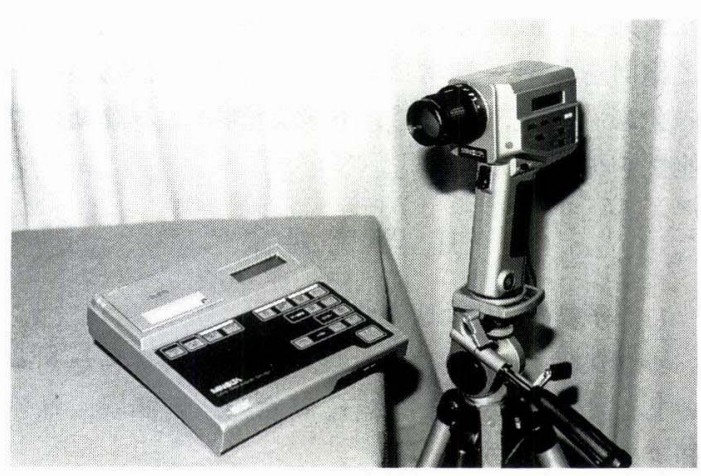

図 2 a 非接触型色彩計, 色彩色差計 CS-100 (右) お よびデータプロセッサーDP-101 (左)（ミノル夕 カメラ(侏製)

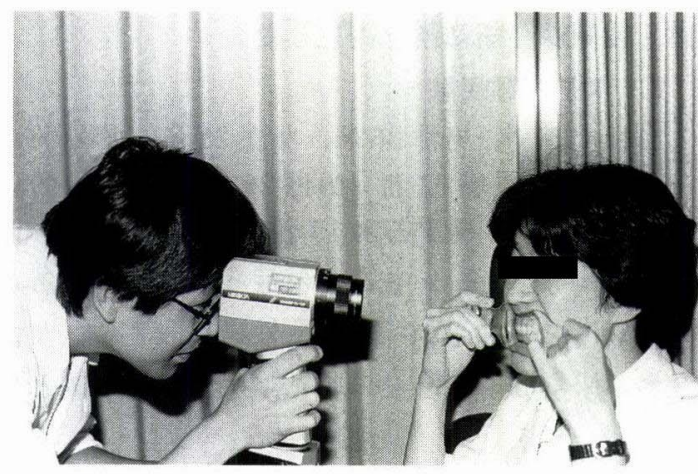

目 $2 \mathrm{~b}$ 非接触型色彩計を用いた口腔粘膜の測色.人 口太陽照明灯により被検部を 45 度の角度から照 明し，垂直方向から測定する 


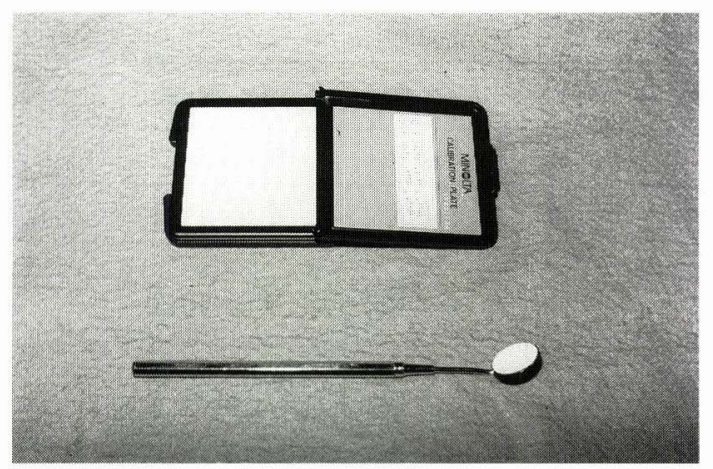

図 3 ミノルタ製標準白色板 (上) と試作したデンタル ミラ一型標準白色板（下）

タルミラー型標準白色板を口腔内に挿入し, 被検 部と同位置，同角度で任意基準校正を行った後に 測定した。

3）口腔粘膜測色の精度・再現性の検討

（1）口腔粘膜の測色精度

3 名の測定者が, 1 名の健常者の下唇, 歯肉, 舌側縁, 煩粘膜の同位置を各 5 回測定し, 口腔粘 膜測色の精度を検討した。

（2）口腔粘膜の測色再現性

1 名の測定者が時間を変えて, 健常者 1 名の下 唇, 歯肉, 舌側縁, 頓粘膜の同位置を各 5 回測定 し，口腔粘膜測色の再現性を検討した。

\section{5. 健常口腔粘膜および口腔粘膜疾患の測色方法}

前記 4.により非接触型色彩計は精度, 再現性と もに優れており，口腔内測色法として最適と判断 されたので，本測定法により，健常口腔粘膜およ び口腔粘膜疾患の測色を行った。口腔粘膜疾患に ついては，生検などの侵襲が加えられていないも ので, 肉眼的観察により, 病変の色彩的変化を代 表すると考えられる部分を測定した。同一病変で 複数の色彩変化を伴っている場合は, 各色彩につ いて測定を行った。また病変部の色彩変化を, 健 常部からの色差として表すために, 周囲健常部あ るいは反対側の色彩を測定した。舌白板症につい ては, 病理組織学的検索が可能であった 27 例につ いて, 上皮性異形成の程度を 1978 年の WHOの 口腔前癌病変調查委員会報告の基準に準じ7), そ
の程度を軽度, 中等度, 高度に分類し, 色彩との 関連を検討した。

\section{IV. 研 究 結 果}

\section{1.色彩計の比較}

1 ) 色票の測定結果

值の与えられている赤, 青, 緑の色票について 接触型色彩計, 非接触型色彩計の 2 種の色彩計を 用いて测定を行った。色票值と実测定值をマンセ ル表色少で比較すると, 接触型色彩計では色相 $0.3 \sim 0.5$, 明度 $0 \sim 0.1$, 彩度 $0.1 \sim 0.7$ の差であ $\eta$, 非接触型色彩計では色相 $0.2 \sim 1.4$, 明度 0 , 彩度は 0.5 の差であった（表 1 )。

なおこれまで応用してきた口腔粘膜比色ス ケールの色彩表示の分割は, 色相 2.5 Hue step, 明度 1 Value step (一部 0.5 Value step), 彩度 2 Chroma step であることを考えると, 口腔粘膜 の測色という点ではきわめて精度は高く, 臨床に 十分応用可能と考えられた。

2 ) 口腔粘膜の測色結果

健常者 2 名の上顎前歯部の唇側付着歯肉, 舌側 縁について, 接触型色彩計および非接触色彩計に よる測定を行い, 視感比色值と比較した。

健常者 2 名の歯肉の視感比色值を, 色相 明度/ 彩度として表すと，10 R 5.0/4.0 および $10 \mathrm{R}$ 5.0/5.0であった。接触型色彩計の測定結果は 5.5 GY 4.9/0.9 および 9.2 GY 4.1/1.7であり，視感 比色值と比べ, 明度は近似していたが, GY (黄緑) という全く采統の違う色相であり, 著しい低彩度 を示していた。非接触型色彩計色彩計の測定結果 は 0.3 YR 4.8/5.0 および0.1 YR 5.2/5.6であ $\eta$, 色相, 明度, 彩度ともに視感比色值に近似し ていた（表 2 a)。

健常者 2 名の舌側縁の視感比色值は $5.0 \mathrm{R}$ 4.0/6.0 および $7.5 \mathrm{R}$ 4.0/5.0 であった。接触型 色彩計の測定結果は 8.7 R 2.9/1.8 および $8.4 \mathrm{R}$ $2.8 / 1.4$ であり, 視感比色值に比べ明度, 彩度は低 值を示し, 歯肉の測色値と同様, 視感比色值とか け離れていた。非接触型色彩計の測定結果は 5.0 R 3.9/5.7 およU゙ 8.6 R 4.4/5.6であり, 色相, 
表 1 接触型, 非接触型彩度計による色票の測定結果

\begin{tabular}{|c|c|c|c|c|c|c|}
\hline & & $\mathrm{Y}$ & $\mathrm{x}$ & $\mathrm{y}$ & 色相 & 明度／彩度 \\
\hline \multirow{3}{*}{ 赤色 票 } & 色 票 值 & 19.7 & 0.4890 & 0.3240 & $5.4 \mathrm{R}$ & $5.0 / 10.7$ \\
\hline & $\begin{array}{c}\text { 接 触 型 } \\
(\mathrm{SD})\end{array}$ & $\begin{array}{l}18.9 \\
(0.1)\end{array}$ & $\begin{array}{c}0.5062 \\
(0.0013)\end{array}$ & $\begin{array}{c}0.3262 \\
(0.0003)\end{array}$ & $5.9 \mathrm{R}$ & $4.9 / 11.4$ \\
\hline & $\begin{array}{c}\text { 非 接触 型 } \\
(\mathrm{SD})\end{array}$ & $\begin{array}{l}20.2 \\
(0.2)\end{array}$ & $\begin{array}{c}0.4894 \\
(0.0002)\end{array}$ & $\begin{array}{c}0.3349 \\
(0.0001)\end{array}$ & $6.8 \mathrm{R}$ & $5.0 / 10.2$ \\
\hline \multirow{3}{*}{ 青 色 票 } & 色 票 值 & 19.2 & 0.2056 & 0.2289 & $0.7 \mathrm{~PB}$ & $4.9 / 8.3$ \\
\hline & $\begin{array}{c}\text { 接 触 型 } \\
(\mathrm{SD})\end{array}$ & $\begin{array}{l}17.7 \\
(0.0)\end{array}$ & $\begin{array}{c}0.1968 \\
(0.0001)\end{array}$ & $\begin{array}{c}0.2177 \\
(0.0001)\end{array}$ & $1.0 \mathrm{~PB}$ & $4.8 / 9.0$ \\
\hline & $\begin{array}{c}\text { 非 接 触 型 } \\
(\mathrm{SD})\end{array}$ & $\begin{array}{l}18.9 \\
(0.1)\end{array}$ & $\begin{array}{c}0.2057 \\
(0.0002)\end{array}$ & $\begin{array}{c}0.2363 \\
(0.0001)\end{array}$ & $9.4 \mathrm{~B}$ & $4.9 / 7.8$ \\
\hline \multirow{3}{*}{ 緑色 票 } & 色 票 值 & 30.0 & 0.3031 & 0.4136 & $0.9 \mathrm{G}$ & $6.0 / 6.3$ \\
\hline & $\begin{array}{c}\text { 接 触 型 } \\
(\mathrm{SD})\end{array}$ & $\begin{array}{l}29.7 \\
(0.1)\end{array}$ & $\begin{array}{c}0.3068 \\
(0.0002)\end{array}$ & $\begin{array}{c}0.4201 \\
(0.0001)\end{array}$ & $0.5 \mathrm{G}$ & $6.0 / 6.4$ \\
\hline & $\begin{array}{c}\text { 非 接 触 型 } \\
(\mathrm{SD})\end{array}$ & $\begin{array}{l}30.0 \\
(0.2)\end{array}$ & $\begin{array}{c}0.3056 \\
(0.0001)\end{array}$ & $\begin{array}{c}0.4076 \\
(0.0001)\end{array}$ & $0.7 \mathrm{G}$ & $6.0 / 5.8$ \\
\hline
\end{tabular}

表 $2 \mathrm{a}$ 接触型, 非接触型色彩計による歯肉の測色結果

\begin{tabular}{|c|c|c|c|c|c|c|}
\hline 被験者 & & Y & $\mathrm{x}$ & $\mathrm{y}$ & 色相 & 明度／彩度 \\
\hline \multirow{3}{*}{ 被験者 A } & 視感比色値 & - & - & - & $10 \mathrm{R}$ & $5.0 / 4.0$ \\
\hline & $\begin{array}{c}\text { 接 触 型 } \\
(\mathrm{SD})\end{array}$ & $\begin{array}{l}18.5 \\
(0.8)\end{array}$ & $\begin{array}{c}0.3180 \\
(0.0041)\end{array}$ & $\begin{array}{c}0.3374 \\
(0.0021)\end{array}$ & $5.5 \mathrm{GY}$ & $4.9 / 0.9$ \\
\hline & $\begin{array}{c}\text { 非 接 触 型 } \\
\text { (SD) }\end{array}$ & $\begin{array}{l}17.8 \\
(1.7)\end{array}$ & $\begin{array}{c}0.4149 \\
(0.0037)\end{array}$ & $\begin{array}{c}0.3466 \\
(0.0013)\end{array}$ & $0.3 \mathrm{YR}$ & $4.8 / 5.0$ \\
\hline \multirow{3}{*}{ 被験者 B } & 視感比色值 & - & - & - & $10 \mathrm{R}$ & $5.0 / 5.0$ \\
\hline & $\begin{array}{c}\text { 接 触 型 } \\
(\mathrm{SD})\end{array}$ & $\begin{array}{l}12.6 \\
(1.5)\end{array}$ & $\begin{array}{c}0.3343 \\
(0.0071)\end{array}$ & $\begin{array}{c}0.3105 \\
(0.0045)\end{array}$ & $9.2 \mathrm{GY}$ & $4.1 / 1.7$ \\
\hline & $\begin{array}{c}\text { 非 接 触 型 } \\
\text { (SD) }\end{array}$ & $\begin{array}{l}21.2 \\
(1.7)\end{array}$ & $\begin{array}{c}0.4173 \\
(0.0037)\end{array}$ & $\begin{array}{c}0.3474 \\
(0.0013)\end{array}$ & $0.1 \mathrm{YR}$ & $5.2 / 5.6$ \\
\hline
\end{tabular}

明度，彩度ともに視感比色值に近似していた（表 $2 \mathrm{~b})$ 。

以上の結果により口腔粘膜の色彩測定におい て, 非接触型色彩計による測定結果が視感比色值 に近似しており，肉眼所見とも一致していた。

\section{2. 色彩色差計 CS-100による口腔粘膜測色法の} 検討

1 ）測定条件の検討

標準光源を用いた場合, 室内照明の有無, 光源 距離, 測定距離の変化による測定值の違いは, 色 相 $0.2[6.7 \mathrm{R} \sim 6.9 \mathrm{R}$ : 実 測 值 $]$, 明度 
表 $2 \mathrm{~b}$ 接触型，非接触型色彩計による舌側縁の色測結果

\begin{tabular}{|c|c|c|c|c|c|c|}
\hline 被験者 & 被験者A & $\mathrm{Y}$ & $\mathrm{x}$ & $\mathrm{y}$ & 色相 & 明度／彩度 \\
\hline \multirow{5}{*}{ 被験者A } & 視感比色值 & - & - & - & $5.0 \mathrm{R}$ & $4.0 / 6.0$ \\
\hline & 接 触 型 & 5.9 & 0.3650 & 0.3260 & $8.7 \mathrm{R}$ & $2.9 / 1.8$ \\
\hline & (SD) & $(0.8)$ & $(0.0041)$ & $(0.0020)$ & & \\
\hline & 非 接 触 型 & 11.3 & 0.4260 & 0.3222 & $5.0 \mathrm{R}$ & $3.9 / 5.7$ \\
\hline & (SD) & $(0.3)$ & $(0.0038)$ & $(0.0009)$ & & \\
\hline \multirow{5}{*}{ 被験者 B } & 視感比色值 & - & - & - & $7.5 \mathrm{R}$ & $4.0 / 5.0$ \\
\hline & 接 触 型 & 5.9 & 0.3519 & 0.3232 & $8.4 \mathrm{R}$ & $2.8 / 1.4$ \\
\hline & $(\mathrm{SD})$ & $(0.3)$ & $(0.0145)$ & $(0.0063)$ & & \\
\hline & 非接触 型 & 14.7 & 0.4276 & 0.3394 & $8.6 \mathrm{R}$ & $4.4 / 5.6$ \\
\hline & $(\mathrm{SD})$ & $(1.1)$ & $(0.0026)$ & $(0.0010)$ & & \\
\hline
\end{tabular}

表 3 測定条件による測定値の変化

\begin{tabular}{lrrrrrrr}
\hline \hline \multicolumn{1}{c}{ 照明 方 法 } & 光源距離 & 測定距離 & $\mathrm{Y}$ & $\mathrm{x}$ & $\mathrm{y}$ & 色相 & 明度/彩度 \\
\hline 室内照明＋標準光源 & $0.5 \mathrm{~m}$ & $323 \mathrm{~mm}$ & 20.0 & 0.4894 & 0.3349 & $6.8 \mathrm{R}$ & $5.0 / 10.2$ \\
室内照明＋標準光源 & $0.5 \mathrm{~m}$ & $368 \mathrm{~mm}$ & 20.6 & 0.4901 & 0.3355 & $6.9 \mathrm{R}$ & $5.1 / 10.3$ \\
室内照明＋標準光源 & $1 \mathrm{~m}$ & $323 \mathrm{~mm}$ & 21.8 & 0.4870 & 0.3355 & $6.8 \mathrm{R}$ & $5.2 / 10.4$ \\
室内照明+標準光源 & $1 \mathrm{~m}$ & $368 \mathrm{~mm}$ & 21.5 & 0.4851 & 0.3346 & $6.7 \mathrm{R}$ & $5.2 / 10.3$ \\
標準光源のみ & $1 \mathrm{~m}$ & $368 \mathrm{~mm}$ & 21.7 & 0.4896 & 0.3348 & $6.7 \mathrm{R}$ & $5.2 / 10.5$ \\
室内照明のみ & $1 \mathrm{~m}$ & $368 \mathrm{~mm}$ & 24.5 & 0.4645 & 0.3434 & $8.0 \mathrm{R}$ & $5.5 / 9.0$ \\
室内照明十デンタルライト & $1 \mathrm{~m}$ & $368 \mathrm{~mm}$ & 21.8 & 0.5135 & 0.3458 & $8.1 \mathrm{R}$ & $5.2 / 11.4$ \\
デンタルライトのみ & $1 \mathrm{~m}$ & $368 \mathrm{~mm}$ & 17.7 & 0.5117 & 0.3483 & $8.6 \mathrm{R}$ & $4.8 / 10.3$ \\
\hline
\end{tabular}

$0.2[5.0 \sim 5.2]$ ，彩度 0.3 [10.2 10.5] であり非 常に小さいと考えられた。標準光源を用いない場 合も入れると, 光源距離, 測定距離を一定にして も，測定值の違いは色相 1.9 [6.7 R 8.6 R]，明 度 0.7 [4.8〜 5.5], 彩度 2.4 [9.0〜 11.4] と大き かった (表 3 )。特に室内照明や, デンタルライト 下の測定值の色相は，YR (橙) 方向へ分布してい た。

以上の結果より，標準光源を用いれば，一定し た測色值が得られることが判明した。なお，被験 者にとって, 光源が近接した状況での測定は熱さ, 眩しさなどの苦痛を伴うため, 本研究では以後, 光源距離を約 $1 \mathrm{~m}$ とした。

2 ）口腔粘膜測色の精度・再現性の検討
（1） 口腔粘膜測色の精度

3 名の測定者が, 1 名の健常者の下唇, 歯肉, 舌側縁，頓粘膜を測定した。その結果，マンセル 表色系における測定値の変動は，下唇では色相 $0.4[7.3 \mathrm{R} \sim 7.7 \mathrm{R}]$ ，明度 0.3 [4.6 4.9]，彩度 0.5 [5.2 5.7], 歯肉では色相 $0.3[9.3 \mathrm{R} \sim 9.6$ $\mathrm{R}]$, 明度 0.2 [4.8 5.0], 彩度 0.1 [5.0 5.1], 舌側縁では色相 $0.7[7.8 \mathrm{R} \sim 8.5 \mathrm{R}]$, 明度 $0.4[4.5 \sim 4.9]$, 彩度 $0.2[5.8 \sim 6.0]$, 煩粘膜で は色相 $0.2[9.3 \mathrm{R} \sim 9.5 \mathrm{R}]$, 明度 $0.3[5.4 \sim 5.7]$, 彩度 0.2 [6.0 6.2] であった（表 4 ）。異なる測 定者において, 色相, 明度, 彩度ともに測定値の 変動は小さかった。

（2）口腔粘膜測色の再現性 
表 4 測定者 3 名による口腔粘膜測色の精度

\begin{tabular}{|c|c|c|c|c|c|c|}
\hline 測定部位 & 測定者 & $\mathrm{Y}$ & $\mathrm{x}$ & $\mathrm{y}$ & 色相 & 明度／彩度 \\
\hline \multirow{3}{*}{ 下 } & A & 17.5 & 0.4161 & 0.3328 & $7.3 \mathrm{R}$ & $4.7 / 5.7$ \\
\hline & B & 19.0 & 0.4042 & 0.3319 & $7.3 \mathrm{R}$ & $4.9 / 5.2$ \\
\hline & $\mathrm{C}$ & 16.7 & 0.4140 & 0.3339 & $7.7 \mathrm{R}$ & $4.6 / 5.4$ \\
\hline \multirow{3}{*}{ 歯 } & A & 17.6 & 0.4134 & 0.3433 & $9.6 \mathrm{R}$ & $4.8 / 5.1$ \\
\hline & B & 19.8 & 0.4063 & 0.3412 & $9.3 \mathrm{R}$ & $5.0 / 5.0$ \\
\hline & $\mathrm{C}$ & 19.7 & 0.4080 & 0.3425 & $9.5 \mathrm{R}$ & $5.0 / 5.0$ \\
\hline \multirow{3}{*}{ 舌 側 縁 } & A & 15.6 & 0.4263 & 0.3363 & $7.9 \mathrm{R}$ & $4.5 / 5.8$ \\
\hline & B & 17.6 & 0.4247 & 0.3361 & $7.8 \mathrm{R}$ & $4.8 / 6.0$ \\
\hline & $\mathrm{C}$ & 18.5 & 0.4239 & 0.3404 & $8.5 \mathrm{R}$ & $4.9 / 5.9$ \\
\hline \multirow{3}{*}{ 规 粘 膜 } & A & 26.4 & 0.4146 & 0.3446 & $9.4 \mathrm{R}$ & $5.7 / 6.1$ \\
\hline & B & 24.0 & 0.4172 & 0.3443 & $9.3 \mathrm{R}$ & $5.4 / 6.0$ \\
\hline & $\mathrm{C}$ & 25.7 & 0.4177 & 0.3455 & $9.5 \mathrm{R}$ & $5.6 / 6.2$ \\
\hline
\end{tabular}

表 5 同一測定者による口腔粘膜測色の再現性

\begin{tabular}{|c|c|c|c|c|c|c|}
\hline 測定部位 & 測定回 & $\mathrm{Y}$ & $\mathrm{x}$ & $\mathrm{y}$ & 色相 & 明度／彩度 \\
\hline \multirow{3}{*}{ 下 } & 1 回目 & 22.3 & 0.3963 & 0.3314 & $7.3 \mathrm{R}$ & $5.3 / 5.1$ \\
\hline & 2 回目 & 25.4 & 0.3945 & 0.3344 & $8.0 \mathrm{R}$ & $5.6 / 5.2$ \\
\hline & 3 回目 & 27.4 & 0.3924 & 0.3337 & $7.8 \mathrm{R}$ & $5.8 / 5.2$ \\
\hline \multirow{3}{*}{ 歯 } & 1 回目 & 16.6 & 0.4223 & 0.3376 & $8.2 \mathrm{R}$ & $4.6 / 5.7$ \\
\hline & 2 回目 & 18.2 & 0.4188 & 0.3382 & $8.3 \mathrm{R}$ & $4.8 / 5.7$ \\
\hline & 3 回目 & 19.6 & 0.4169 & 0.3374 & $8.1 \mathrm{R}$ & $5.0 / 5.8$ \\
\hline \multirow{3}{*}{ 舌 側 縁 } & 1 回目 & 18.1 & 0.4073 & 0.3279 & $6.2 \mathrm{R}$ & $4.8 / 5.5$ \\
\hline & 2 回目 & 15.3 & 0.4104 & 0.3328 & $7.6 \mathrm{R}$ & $4.5 / 5.0$ \\
\hline & 3 回目 & 17.3 & 0.4109 & 0.3341 & $7.8 \mathrm{R}$ & $4.7 / 5.3$ \\
\hline \multirow{3}{*}{ 顂 粘 膜 } & 1 回目 & 28.4 & 0.3908 & 0.3352 & $8.3 \mathrm{R}$ & $5.9 / 5.1$ \\
\hline & 2 回目 & 27.0 & 0.3918 & 0.3310 & $7.1 \mathrm{R}$ & $5.7 / 5.3$ \\
\hline & 3 回目 & 28.0 & 0.3918 & 0.3336 & $7.8 \mathrm{R}$ & $5.8 / 5.2$ \\
\hline
\end{tabular}

1名の測定者が時間を変えて，1名の健常者の 下唇，歯肉，舌側縁，煩粘膜を測定した。その結 果, マンセル表色系における測定值の変動は, 下 唇では色相 $0.7[7.3 \mathrm{R} \sim 8.0 \mathrm{R}]$, 明度 0.5 [5.3 5.8], 彩度 0.1 [5.1 5.2], 歯肉では 色相 0.2 [8.1 R 8.3 R], 明度 0.4 [4.6 5.0], 彩度 0.1 [5.7 5.8], 舌側縁では色相 $1.6[6.2 \mathrm{R}$ $\sim 7.8 \mathrm{R}]$, 明度 $0.3[4.5 \sim 4.8]$, 彩 度
0.5 [5.0 5.5]，煩粘膜では色相 $1.2[7.1 \mathrm{R} \sim 8.3$ $\mathrm{R}]$, 明度 0.2 [5.7 5.9], 彩度 0.2 [5.1 5.3] であった(表 5 )。測定時間が異なっても色相，明 度, 彩度ともに測定值の変動は小さかった。

以上の結果により, 色彩色差計 CS-100 は口腔 粘膜の測色においても, 精度, 再現性ともに優れ ていた。 


\section{3. 健常口腔粘膜の測色結果}

色彩色差計 CS-100 を用いて，20３0 歳代の健 常成人 35 名（男性 23 名，女性 12 名）の下唇，上 顎前歯部の唇側付着歯肉, 舌側縁, 頬粘膜につい て測色を行った。なお，明らかな男女差が認めら れなかったことから男女，合わせて結果を示す。 また下唇の色相分布は煩粘膜に類似し, 明度・彩 度分布は舌側縁, 歯肉に類似しているため, 図か らは省略した（表 6 , 図 4 ）。

マンセル表色系における健常口腔粘膜の色彩 は, 色相 $5.0 \mathrm{R} \sim 4.1 \mathrm{YR}$, 明度 3.5 6.0, 彩度 $3.7 \sim 6.7$ に分布していた。各部位の色彩分布を比 較してみると，色相については，下唇は $6.8 \mathrm{R}$ $\sim 3.2 \mathrm{YR}$ (平均 $9.77 \mathrm{R}$ ), 歯肉は $8.9 \mathrm{R} \sim 4.1 \mathrm{YR}$

(平均 $1.27 \mathrm{YR}$ ), 舌側縁は $5.0 \mathrm{R} \sim 0.9 \mathrm{YR}$ (平均 $7.99 \mathrm{R}$ )，煩粘膜は $6.8 \mathrm{R} \sim 3.3 \mathrm{YR}$ (平均 0.30 YR)に分布しており, 頓粘膜, 下唇に比べ, 歯肉
では YR 方向に分布し橙色傾向を, 舌側縁では $\mathrm{R}$ 方向に分布し赤色傾向を示す結果であった。明度 については, 下唇は 3.5 5.2 (平均 4.42), 歯肉 は 4.2 5.4 (平均 4.82), 舌側縁は 3.8 5.3 (平 均 4.56), 頓粘膜 4.5 6.0 (平均 5.42) に分布し ており，頓粘膜の明度は他に比べ高い傾向であっ た。彩度については,下唇は 3.8～5.8(平均 4.75), 歯肉は $3.7 \sim 6.2$ (平均 4.98 ), 舌側縁は $4.4 \sim 6.4$ (平均 5.18), 煩粘膜は 4.6 6.7 (平均 5.76）であり，煩粘膜の彩度は他に比べ高い傾向 であった。

\section{4. 口腔粘膜疾患の測色結果}

1) 白板症

57 名（男性 36 名, 女性 21 名）の白板症患者の 81 部位 (舌 48 部位, 歯肉 24 部位, 頓粘膜 9 部位) の色彩について, 色彩色差計を用い測定を行った。 また, 病変部は白斑部と紅斑部に分けて比較した。

表 6 健常者 35 名の口腔粘膜の色彩分布（マンセル表色系）

\begin{tabular}{|c|c|c|c|c|c|c|c|c|c|c|c|c|c|c|c|}
\hline & & \multirow[b]{2}{*}{ 部位数 } & \multicolumn{3}{|c|}{ 色 } & \multicolumn{2}{|l|}{ 相 } & \multicolumn{2}{|r|}{ 明 } & \multicolumn{2}{|c|}{ 度 } & \multicolumn{2}{|r|}{ 彩 } & \multicolumn{2}{|c|}{ 度 } \\
\hline & & & 範 & 囲 & 平 & 均 & (SD) & 範 & 囲 & 平均 & (SD) & 範 & 囲 & 平均 & (SD) \\
\hline \multicolumn{3}{|c|}{ 健常口腔粘膜 140} & \multicolumn{2}{|c|}{$5.0 \mathrm{R}-4.1 \mathrm{YR}$} & \multicolumn{2}{|c|}{$9.83 \mathrm{R}$} & $(1.87)$ & \multicolumn{2}{|c|}{$3.5-6.0$} & 4.80 & $(0.53)$ & \multicolumn{2}{|c|}{$3.7-6.7$} & 5.16 & $(0.61)$ \\
\hline 下 & & 唇 35 & \multicolumn{2}{|c|}{$6.8 \mathrm{R}-3.2 \mathrm{YR}$} & \multicolumn{2}{|c|}{$9.77 \mathrm{R}$} & $(1.41)$ & \multicolumn{2}{|c|}{$3.5-5.2$} & 4.42 & $(0.38)$ & \multicolumn{2}{|c|}{$3.8-5.8$} & 4.75 & $(0.52)$ \\
\hline 歯 & & 肉 35 & \multicolumn{2}{|c|}{$8.9 \mathrm{R}-4.1 \mathrm{YR}$} & \multicolumn{2}{|c|}{$1.27 \mathrm{YR}$} & $(1.30)$ & & $2-5.4$ & 4.82 & $(0.35)$ & \multicolumn{2}{|c|}{$3.7-6.2$} & 4.98 & $(0.49)$ \\
\hline 舌 & 跑 & 緑 35 & \multicolumn{2}{|c|}{$5.0 \mathrm{R}-0.9 \mathrm{YR}$} & \multicolumn{2}{|c|}{$7.99 \mathrm{R}$} & $(1.28)$ & & $8-5.3$ & 4.56 & $(0.37)$ & \multicolumn{2}{|c|}{$4.4-6.4$} & 5.18 & $(0.50)$ \\
\hline 煩 & 粘 & 膜 35 & \multicolumn{2}{|c|}{$6.8 \mathrm{R}-3.3 \mathrm{YR}$} & \multicolumn{2}{|c|}{$0.30 \mathrm{YR}$} & $(1.76)$ & & $5-6.0$ & 5.42 & $(0.36)$ & \multicolumn{2}{|c|}{$4.6-6.7$} & 5.76 & $(0.46)$ \\
\hline
\end{tabular}

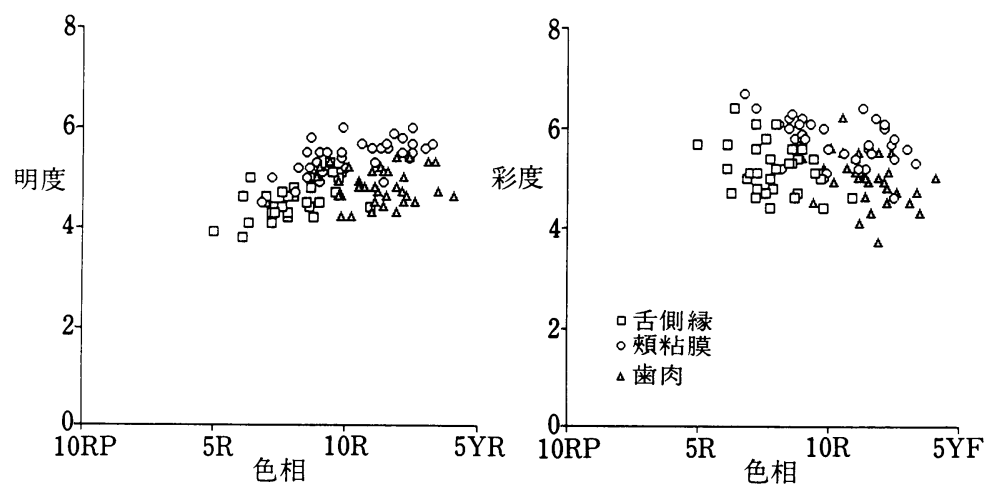

図 4 健常口腔粘膜の色彩分布（マンセル表色系） 
紅斑部 15 部位のうち 12 部位は舌白板症に認めら れたものであった。

（1） マンセル表色系による白板症の色彩

白板症の色相は2.6 RP 3.4 Y, 明度は 3.7〜 7.0, 彩度は 0.3 8.3に分布していた。色相 は健常粘膜に比へ，広い範囲にわたり分布してお $\eta$ ，健常粘膜ではみられなかった $\mathrm{RP}$ (赤紫)や $\mathrm{Y}$

(黄)といった色相も認められた。色相の平均は, 白斑部が $5.80 \mathrm{R}$ (SD：4.18)，紅斑部が $6.10 \mathrm{R}$

(SD：0.63) であり，いずれも健常粘膜に比べ $\mathrm{R}$ 方向に位置していた。また白斑部の色相は $2.6 \mathrm{RP}$ 〜3.4Y と広範囲にわたっているのに対し，紅斑 部の色相は $5.0 \mathrm{R} \sim 7.0 \mathrm{R}$ と狭い範囲に分布して いた。

明度は3.7〜 7.0に分布し, 白斑部は平均 $5.24(\mathrm{SD}: 0.59)$, 紅斑部は平均 $4.52(\mathrm{SD}: 0.43)$ であり，白斑部は紅斑部，健常粘膜に比べやや高 かった。

彩度については $0.3 \sim 8.3$ と, 健常粘膜に比べ広 範囲に分布していた。白斑部の彩度は，平均 $3.60 （ \mathrm{SD} ： 1.09 ）$ と低く，健常粘膜にはみられな かった 0.3 といった非常に彩度の低い色も認めら れた。これに対し, 紅斑部の彩度は平均
6.07 (SD：1.20）と高く，8.3 といった高彩度の 色まで認められた。

各部位における白板症の色彩を比較すると，白 斑部の色相については，舌白板症は $2.6 \mathrm{RP} \sim 1.5$ $\mathrm{YR}$ (平均 $5.28 \mathrm{R}$ )，歯肉白板症は $1.0 \mathrm{R} \sim 6.3 \mathrm{YR}$

(平均 $6.85 \mathrm{R}$ ) であり, 健常粘膜と同様に，歯肉 白板症は舌白板症より YR 方向に分布していた

(表 7 , 図 5 a)。

（2） L*a*b*表色系による白板症の色彩

$\mathrm{L}^{*} \mathrm{a}^{*} \mathrm{~b}^{*}$ 表色系を用いて, 白板症の色彩を周囲健 常粘膜からの色差として表すと, 明度 $\Delta \mathrm{L}^{*}$ は白斑 部で 66 部位中 55 部位で正の值を, 紅斑部で 15 部 位中 10 部位で負の值を示した。また色度 $\Delta \mathrm{a}^{*}$ と $\Delta \mathrm{b}^{*}$ は正の相関を示す傾向にあり，白斑部では 66 部位中 63 部位で $\Delta \mathrm{a}^{*}, \Delta \mathrm{b}^{*}$ ともに負の值を示 した（図 5 b)。

（3）上皮性異形性と色彩

組織学的に検索し得た舌白板症 27 部位の上皮 性異形成の有無および程度は, 上皮性異形成を認 めないものが 2 例，軽度なものが 9 例，中等度な ものが 7 例，高度なものが 9 例であった。

色相，明度については上皮性異形成の程度によ る分布の一定の傾向を認めるにはいたらなかっ

表 7 白板症 57 例の色彩分布（マンセル表色系）

\begin{tabular}{|c|c|c|c|c|c|c|c|c|c|c|c|}
\hline & \multirow{2}{*}{\multicolumn{2}{|c|}{ 部位数 }} & 色 & \multicolumn{2}{|l|}{ 相 } & \multicolumn{2}{|l|}{ 明 } & 度 & \multicolumn{2}{|l|}{ 彩 } & 度 \\
\hline & & & 囲 & 平 均 & $(\mathrm{SD})$ & 範 囲 & 平均 & $(\mathrm{SD})$ & 範 囲 & 平均 & $(\mathrm{SD})$ \\
\hline \multirow[t]{3}{*}{ 白 } & 症 & 81 & $2.6 \mathrm{RP}-3.4 \mathrm{Y}$ & $5.85 \mathrm{R}$ & $(3.78)$ & $3.7-7.0$ & 5.13 & $(0.63)$ & $0.3-8.3$ & 4.02 & $(1.43)$ \\
\hline & 白斑部 & 66 & $2.6 \mathrm{RP}-3.4 \mathrm{Y}$ & $5.80 \mathrm{R}$ & $(4.18)$ & $3.8-7.0$ & 5.24 & $(0.59)$ & $0.3-6.0$ & 3.60 & $(1.09)$ \\
\hline & 紅斑部 & 15 & $5.0 \mathrm{R}-7.0 \mathrm{R}$ & $6.10 \mathrm{R}$ & $(0.63)$ & $3.7-5.3$ & 4.52 & $(0.43)$ & $4.3-8.3$ & 6.07 & $(1.20)$ \\
\hline \multirow[t]{3}{*}{ 舌 } & 板 症 & & $2.6 \mathrm{RP}-1.5 \mathrm{YR}$ & $5.28 \mathrm{R}$ & $(3.09)$ & $3.7-6.6$ & 5.09 & $(0.56)$ & $1.2-8.3$ & 4.05 & $(1.54)$ \\
\hline & 白斑部 & 36 & 2.6 PR-1.5 YR & $5.04 \mathrm{R}$ & $(3.53)$ & $3.9-6.6$ & 5.15 & $(0.54)$ & $1.2-4.9$ & 3.67 & $(0.93)$ \\
\hline & 紅斑部 & 12 & $5.0 \mathrm{R}-7.0 \mathrm{R}$ & $5.99 \mathrm{R}$ & $(0.63)$ & $3.7-5.3$ & 4.62 & $(0.41)$ & $4.6-8.3$ & 6.12 & $(1.10)$ \\
\hline \multirow[t]{3}{*}{ 歯肉 } & 板斑症 & 24 & $1.0 \mathrm{R}-6.3 \mathrm{YR}$ & $6.85 \mathrm{R}$ & $(3.20)$ & $3.8-6.6$ & 5.31 & $(0.58)$ & $2.3-6.0$ & 4.22 & $(0.92)$ \\
\hline & 白斑部 & 23 & $1.0 \mathrm{R}-6.3 \mathrm{YR}$ & $6.89 \mathrm{R}$ & $(3.27)$ & $3.8-6.6$ & 5.29 & $(0.57)$ & $2.3-6.0$ & 4.23 & $(0.93)$ \\
\hline & 紅斑部 & 1 & - & $5.9 \mathrm{R}$ & - & - & 5.9 & - & - & 3.8 & - \\
\hline \multirow{3}{*}{\multicolumn{2}{|c|}{$\begin{array}{r}\text { 煩粘膜白板症 } \\
\text { 白斑部 } \\
\text { 糽斑部 }\end{array}$}} & 9 & $7.4 \mathrm{RP}-3.4 \mathrm{YR}$ & $6.26 \mathrm{R}$ & $(7.22)$ & $3.9-7.0$ & 5.26 & $(0.96)$ & $0.3-7.0$ & 3.37 & $(1.89)$ \\
\hline & & 7 & $7.4 \mathrm{RP}-3.4 \mathrm{YR}$ & $6.09 \mathrm{R}$ & $(8.33)$ & $4.5^{-7.0}$ & 5.57 & $(0.83)$ & $0.3-3.9$ & 2.71 & $(1.39)$ \\
\hline & & 2 & $6.8 \mathrm{R}-6.9 \mathrm{R}$ & $6.85 \mathrm{R}$ & $(0.07)$ & $3.9-4.4$ & 4.15 & $(0.35)$ & $4.3-7.0$ & 5.65 & $(1.90)$ \\
\hline
\end{tabular}



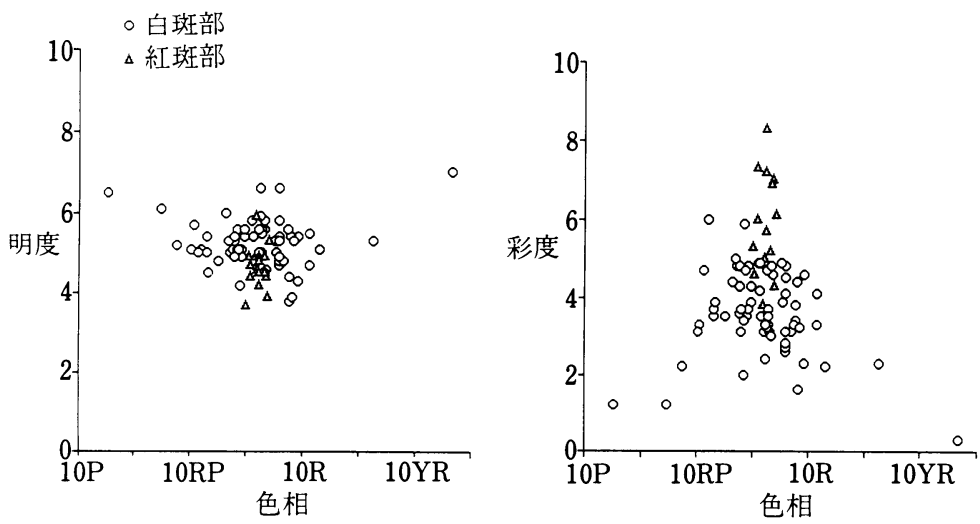

図 $5 \mathrm{a}$ 白板症の色彩分布（マンセル表色系）
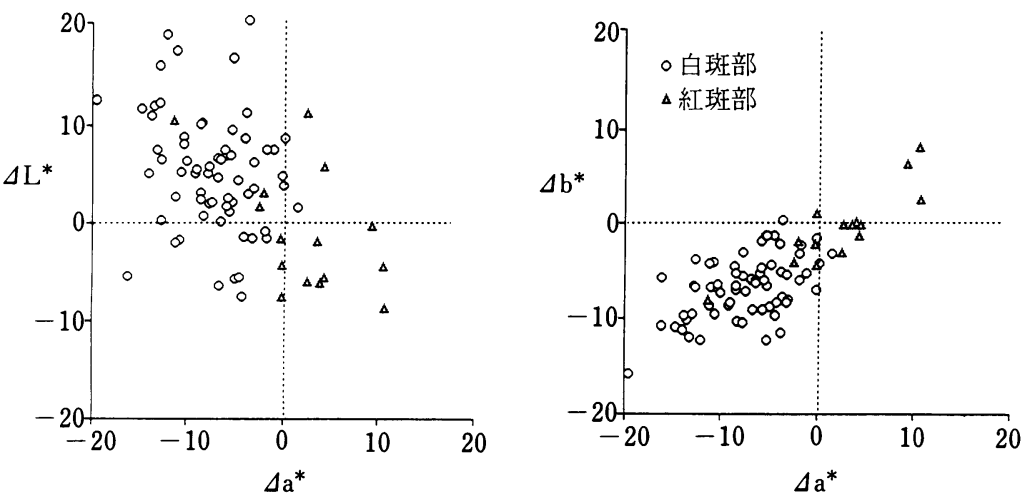

図 $5 \mathrm{~b}$ 白板症の色差分布 $\left(\mathrm{L}^{*} \mathrm{a}^{*} \mathrm{~b}^{*}\right.$ 表色系)

た。彩度については，上皮性異形成との関連がみ られ, 程度が高度になるに従って, 彩度は高くな る傾向にあり, 彩度 6 以上のものはすべて上皮性 異形成が高度であった（表 8 ，図 6 a)。また上皮 性異形成と色差との関係をみると，上皮性異形性 が高度なもの 9 部位中 6 部位で明度 $\Delta \mathrm{L}^{*}$ が負の 值を示し， 3 部位で色度 $\Delta \mathrm{a}^{*}, \Delta \mathrm{b}^{*}$ がいずれも正 の値を示していた（図 $6 \mathrm{~b}$ )。

2 ) 扁平上皮癌

扁平上皮癌患者 62 名（男性 26 名，女性 36 名） の病変について测色を行った。早期浸潤癌8) (以下 早期癌と略す）患者は 5 名， 7 部位（舌 5 部位, 歯肉 1 部位，煩粘膜 1 部位), 進行癌 (早期癌より も進行した扁平上皮癌) 患者は 57 名，73 部位 (舌 57 部位, 歯肉 8 部位, 煩粘膜 8 部位) であった。
また, 病変部は白色部と赤色部に分けて比較した。

（1）マンセル表色系による扁平上皮癌の色彩 進行癌の色相は $3.0 \mathrm{R} \sim 8.2 \mathrm{YR}$, 明度は 2.7〜6.4, 彩度は 3.0〜7.8に分布していた。また 早期癌の色相は $4.2 \mathrm{R} \sim 8.3 \mathrm{R}$ ，明度は $4.2 \sim 6.0$, 彩度は 3.9 6.5に分布していた。

進行癌の色相は, 白板症でみられた $\mathrm{RP}, \mathrm{Y}$ と いった色相はみられず，白板症よりも狭い範囲に 分布していた。また早期癌の色相は進行癌よりも さらに狭い範囲に分布していた。

進行癌の明度は, 白色部が平均 4.77（SD： 0.83 ）, 赤色部が 4.25 (SD：0.58）であり, 白板 症の白斑部，紅斑部と比べ，いずれも白板症より やや低明度の傾向であったが，早期癌の明度は白 板症に類似していた。 
表 8 舌白板症の上皮性異形成と色彩分布（マンセル表色系）

\begin{tabular}{|c|c|c|c|c|c|c|c|c|c|c|c|c|c|c|c|}
\hline \multirow{2}{*}{\multicolumn{2}{|c|}{ 上皮性異形| }} & \multirow{2}{*}{\multicolumn{2}{|c|}{ 部位数 }} & \multicolumn{2}{|r|}{ 色 } & \multicolumn{2}{|l|}{ 相 } & \multicolumn{2}{|r|}{ 明 } & \multicolumn{2}{|c|}{ 度 } & \multicolumn{2}{|r|}{ 彩 } & \multicolumn{2}{|c|}{ 度 } \\
\hline & & & & 範 & 囲 & 平 均 & (SD) & 範 & 囲 & 平均 & (SD) & 範 & 囲 & 平均 & (SD) \\
\hline な & & L & 2 & \multicolumn{2}{|c|}{$4.5 \mathrm{R}-9.1 \mathrm{R}$} & $6.80 \mathrm{R}$ & $(3.25)$ & \multicolumn{2}{|c|}{$3.9-4.2$} & 4.05 & $(0.21)$ & \multicolumn{2}{|c|}{$1.6-3.5$} & 2.55 & $(1.34)$ \\
\hline 軽 & \multirow{3}{*}{ 等 } & 度 & 9 & \multicolumn{2}{|c|}{$8.8 \mathrm{RP}-8.0 \mathrm{R}$} & $4.68 \mathrm{R}$ & $(3.28)$ & \multicolumn{2}{|c|}{$4.6-5.8$} & 5.19 & $(0.35)$ & \multicolumn{2}{|c|}{$2.2-4.6$} & 3.28 & $(0.78)$ \\
\hline 中 & & 度 & 7 & \multicolumn{2}{|c|}{$4.0 \mathrm{R}-6.7 \mathrm{R}$} & $5.34 \mathrm{R}$ & $(0.99)$ & \multicolumn{2}{|c|}{$4.5-5.6$} & 4.96 & $(0.34)$ & \multicolumn{2}{|c|}{$3.0-5.7$} & 4.07 & $(1.03)$ \\
\hline 高 & & 度 & 9 & \multicolumn{2}{|c|}{$0.3 \mathrm{R}-7.0 \mathrm{R}$} & $5.27 \mathrm{R}$ & $(2.05)$ & \multicolumn{2}{|c|}{$4.2-5.7$} & 4.89 & $(0.48)$ & \multicolumn{2}{|c|}{$3.3-8.3$} & 5.78 & $(1.79)$ \\
\hline
\end{tabular}
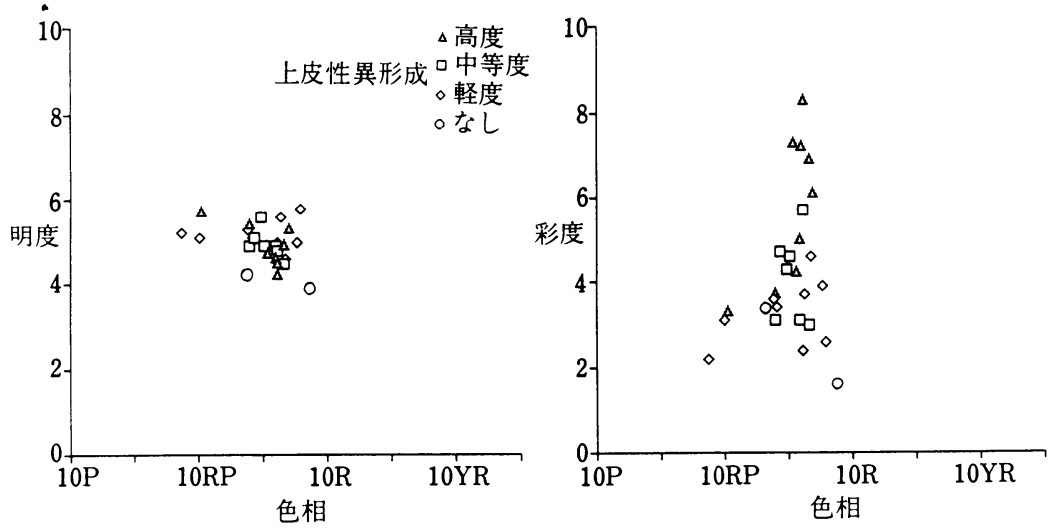

図 $6 \mathrm{a}$ 舌白板症の上皮性異形成と色彩分布（マンセル表色系）
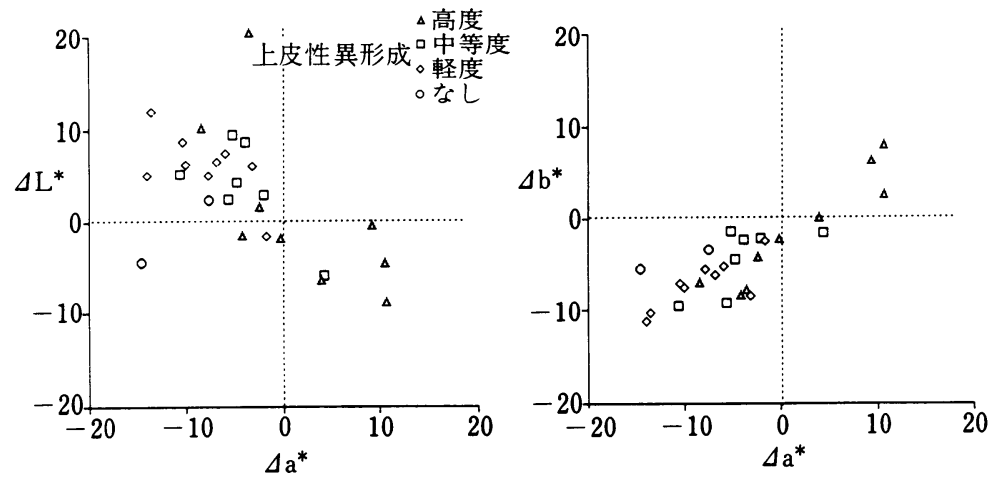

図 $6 \mathrm{~b}$ 舌白板症の上皮性異形成と色差分布 ( $\mathrm{L}^{*} \mathrm{a}^{*} \mathrm{~b}^{*}$ 表色系)

進行癌・早期癌の白色部の彩度の平均はそれぞ れ 4.28（SD：0.97），4.63（SD：0.64）であり， 白板症の白斑部より高く，白板症に多くみられた $0.3 \sim 3.0$ といった低彩度のものは認めなられな かった（表 9 ，図 7 a)。
（2） L*a* b*表色系による扁平上皮癌の色彩 進行癌の明度 $\Delta \mathrm{L}^{*}$ は, 白色部では 16 部位中 10 部位が正の值を，赤色部では 57 部位中 40 部位が 負の值を示した。色度 $\Delta \mathrm{a}^{*}, \Delta \mathrm{b}^{*}$ は, 白色部では 16 部位中 11 部位が $\Delta \mathrm{a}^{*}, \Delta \mathrm{b}^{*}$ がともに負の值 
表 9 扁平上皮癌 62 例の色彩分布（マンセル表色系）

\begin{tabular}{|c|c|c|c|c|c|c|c|c|c|c|c|c|}
\hline & & \multirow{2}{*}{\multicolumn{2}{|c|}{ 部位数 }} & 色 & \multicolumn{2}{|l|}{ 相 } & \multicolumn{2}{|l|}{ 明 } & 度 & \multicolumn{2}{|l|}{ 彩 } & 度 \\
\hline & & & & 囲 & 平 均 & (SD) & 範＼cjkstart囲 & 平均 & (SD) & 範＼cjkstart囲 & 平均 & (SD) \\
\hline \multirow[t]{3}{*}{ 進 } & 行 & 癌 & 73 & $3.0 \mathrm{R}-8.2 \mathrm{YR}$ & $7.18 \mathrm{R}$ & $(2.22)$ & $2.7-6.4$ & 4.35 & $(0.67)$ & $3.0-7.8$ & 5.19 & $(1.10)$ \\
\hline & 白 色 & 部 & 16 & $3.5 \mathrm{R}-8.2 \mathrm{YR}$ & $7.78 \mathrm{R}$ & $(3.44)$ & $3.5-6.4$ & 4.77 & $(0.83)$ & $3.0-6.2$ & 4.28 & $(0.97)$ \\
\hline & 赤色 & 部 & 57 & $3.0 \mathrm{R}-2.0 \mathrm{YR}$ & $7.01 \mathrm{R}$ & $(1.75)$ & $2.7-5.4$ & 4.23 & $(0.57)$ & $3.5^{-7.8}$ & 5.44 & $(1.01)$ \\
\hline \multirow[t]{3}{*}{ 金 } & 進 行 & 癌 & & $3.0 \mathrm{R}-2.0 \mathrm{YR}$ & $6.91 \mathrm{R}$ & $(1.79)$ & $2.7-5.5$ & 4.28 & $(0.62)$ & $3.2-7.3$ & 5.28 & $(1.01)$ \\
\hline & 白 色 & 部 & 12 & $3.5 \mathrm{R}-0.2 \mathrm{YR}$ & $7.13 \mathrm{R}$ & $(2.21)$ & $3.5-5.5$ & 4.52 & $(0.74)$ & $3.2-6.2$ & 4.48 & $(1.01)$ \\
\hline & 赤色 & 部 & 45 & $3.0 \mathrm{R}-2.0 \mathrm{YR}$ & $6.85 \mathrm{R}$ & $(1.68)$ & $2.7-5.4$ & 4.22 & $(0.57)$ & $3.6^{-7.3}$ & 5.49 & $(0.92)$ \\
\hline \multirow[t]{3}{*}{ 首 } & 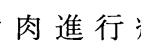 & 癌 & 8 & $4.7 \mathrm{R}-8.2 \mathrm{YR}$ & $0.23 \mathrm{YR}$ & $(4.12)$ & $3.2-6.4$ & 4.56 & $(1.03)$ & $3.4-7.2$ & 4.73 & $(1.16)$ \\
\hline & 白 色 & 部 & 3 & $4.7 \mathrm{R}-8.2 \mathrm{YR}$ & $0.23 \mathrm{YR}$ & $(7.07)$ & $5.1-6.4$ & 5.53 & $(0.75)$ & $3.4-4.2$ & 3.90 & $(0.44)$ \\
\hline & 赤色 & 部 & 5 & $7.1 \mathrm{R}-1.5 \mathrm{YR}$ & $8.88 \mathrm{R}$ & $(1.91)$ & $3.2-4.7$ & 3.98 & $(0.66)$ & $4.0-7.2$ & 5.22 & $(1.20)$ \\
\hline \multirow[t]{3}{*}{ 煩 } & 粘膜進行 & F癌 & 8 & $5.2 \mathrm{R}-9.4 \mathrm{R}$ & $6.88 \mathrm{R}$ & $(1.52)$ & $4.0-5.5$ & 4.59 & $(0.56)$ & $3.0-7.8$ & 5.03 & $(1.61)$ \\
\hline & 白 色 & 部 & 1 & - & $8.3 \mathrm{R}$ & - & - & 5.5 & - & - & 3.0 & - \\
\hline & 赤 色 & 部 & 7 & $5.2 \mathrm{R}-9.4 \mathrm{R}$ & $6.67 \mathrm{R}$ & $(1.52)$ & $4.0-5.4$ & 4.56 & $(0.46)$ & $3.5^{-7.8}$ & 5.31 & $(1.50)$ \\
\hline \multirow[t]{3}{*}{ 早 } & 期 & 癌 & 7 & $4.2 \mathrm{R}-8.3 \mathrm{R}$ & $6.34 \mathrm{R}$ & $(1.29)$ & $4.2-6.0$ & 4.96 & $(0.65)$ & $3.9-6.5$ & 5.46 & $(0.99)$ \\
\hline & 白 色 & 部 & 3 & $4.2 \mathrm{R}-8.3 \mathrm{R}$ & $6.60 \mathrm{R}$ & $(2.14)$ & $5.0-6.0$ & 5.37 & $(0.55)$ & $3.9-5.0$ & 4.63 & $(0.64)$ \\
\hline & 赤 色 & 部 & 4 & $5.7 \mathrm{R}-6.7 \mathrm{R}$ & $6.15 \mathrm{R}$ & $(0.41)$ & $4.2-5.5$ & 4.65 & $(0.59)$ & $5.0-6.5$ & 6.08 & $(0.72)$ \\
\hline
\end{tabular}
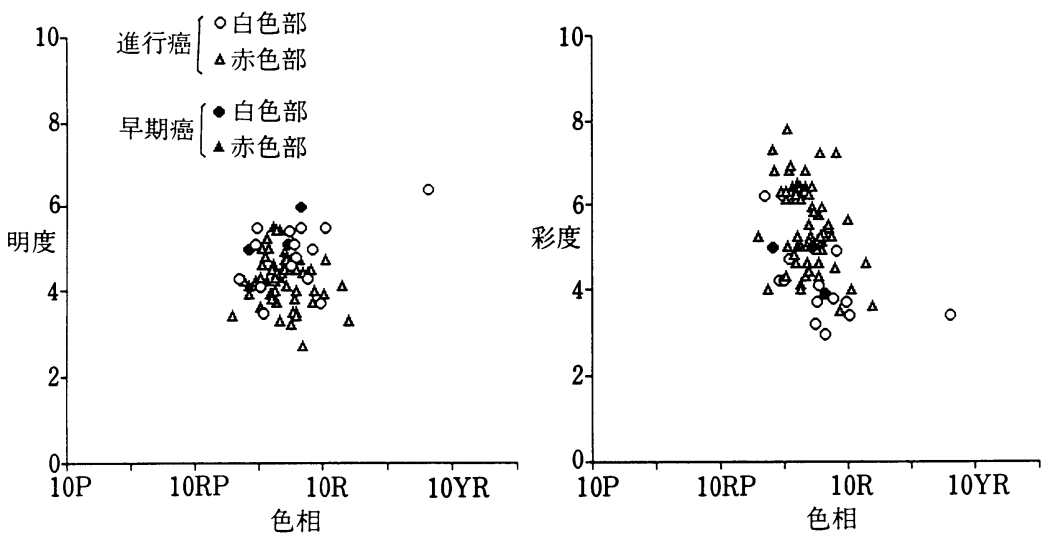

図 $7 \mathrm{a}$ 扁平上皮癌の色彩分布（マンセル表色系）

を，赤色部では 57 部位中 33 部位が $\Delta \mathrm{a}^{*}, \Delta \mathrm{b}^{*}$ が ともに正の值を示した。これら白色部，赤色部の 色差は，それぞれ白板症の白斑部，紅斑部に類似 した分布傾向を示したが，ばらついていた。早期 癌の明度 $\Delta \mathrm{L}^{*}$ は進行癌と同様であったが, 色度 $\Delta$ $\mathrm{a}^{*}, \Delta \mathrm{b}^{*}$ については, 7 部位中 5 部位が $\Delta \mathrm{a}^{*}$ は正 の值を示し, $\Delta \mathrm{b}^{*}$ は負の值を示していた(図 $7 \mathrm{~b}$ )。

\section{3 ) 扁平苔癬}

扁平苔癄 13 名（男性 2 名, 女性 11 名)の 19 部 位について，色彩色差計を用いて病変部色彩の測 定を行った。また，病変部は白斑部 5 部位と紅斑 部 14 部位に分けて比較した。

（1）マンセル表色系による扁平苔癬の色彩 扁平苔癬の色相は $1.7 \mathrm{R} \sim 8.9 \mathrm{R}$, 明度は 

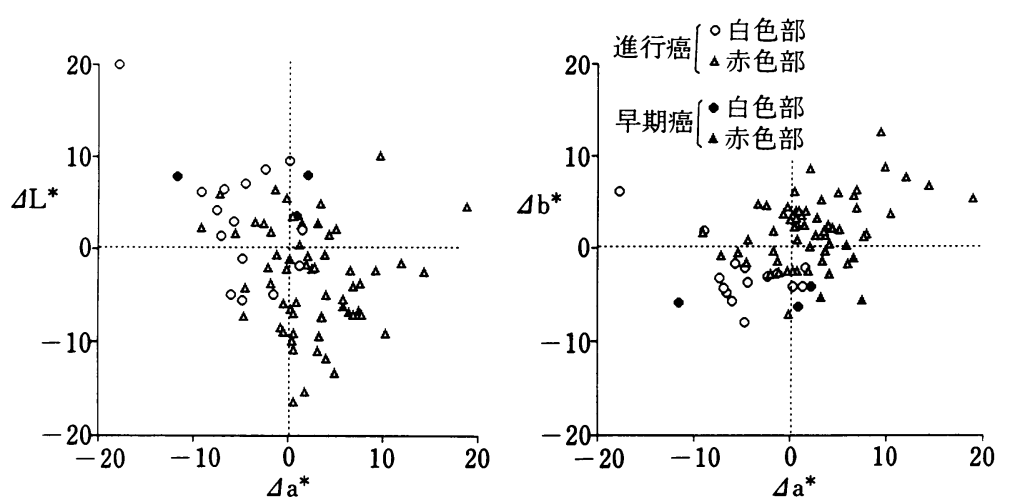

図 $7 \mathrm{~b}$ 扁平上皮癌の色差分布 ( $\mathrm{L}^{*} \mathrm{a}^{*} \mathrm{~b}$ *表色系)

表 10 扁平苔癬 13 例の色彩分布（マンセル表色系）

\begin{tabular}{|c|c|c|c|c|c|c|c|c|c|c|}
\hline & \multirow[b]{2}{*}{ 部位数 } & 色 & \multicolumn{2}{|c|}{ 相 } & \multicolumn{2}{|l|}{ 明 } & 度 & \multicolumn{2}{|l|}{ 彩 } & \multirow{2}{*}{$\frac{\text { 度 }}{(\mathrm{SD})}$} \\
\hline & & 範 囲 & 平均 & (SD) & 範 囲 & 平均 & (SD) & 範 囲 & 平均 & \\
\hline 扁平苔癬 & 19 & 1.7 R-8.9 R & $5.41 \mathrm{R}$ & $(1.72)$ & $3.5-6.3$ & 4.76 & $(0.84)$ & $3.6-8.5$ & 6.34 & $(1.30)$ \\
\hline 白班部 & 5 & $1.7 \mathrm{R}-8.9 \mathrm{R}$ & $5.78 \mathrm{R}$ & $(2.75)$ & $4.4-6.3$ & 5.56 & $(0.70)$ & $3.6-6.0$ & 4.90 & $(0.87)$ \\
\hline 紅班部 & 14 & $3.3 \mathrm{R}-7.1 \mathrm{R}$ & $5.28 \mathrm{R}$ & $(1.31)$ & $3.5-5.4$ & 4.48 & $(0.71)$ & $5.3-8.5$ & 6.85 & $(1.02)$ \\
\hline 舌扁平苔癬 & 5 & 1.7 R-6.9 R & $5.24 \mathrm{R}$ & $(2.13)$ & $3.8-5.6$ & 4.56 & $(0.82)$ & $3.6-6.7$ & 5.28 & $(1.21)$ \\
\hline 白班部 & 2 & $1.7 \mathrm{R}-4.8 \mathrm{R}$ & $3.25 \mathrm{R}$ & $(2.19)$ & $4.4-5.6$ & 5.00 & $(0.85)$ & $3.6-4.7$ & 4.15 & $(0.78)$ \\
\hline 紅班部 & 3 & $6.2 \mathrm{R}-6.9 \mathrm{R}$ & $6.57 \mathrm{R}$ & $(0.35)$ & $3.8-5.2$ & 4.27 & $(0.81)$ & $5.3-6.7$ & 6.03 & $(0.70)$ \\
\hline 歯肉扁平苔痽 & 4 & $3.3 \mathrm{R}-8.9 \mathrm{R}$ & $6.33 \mathrm{R}$ & $(2.34)$ & $3.9-5.7$ & 4.78 & $(0.86)$ & $5.1-8.5$ & 6.85 & (1.43) \\
\hline 白班部 & 1 & - & $8.9 \mathrm{R}$ & - & - & 5.7 & - & - & 5.1 & - \\
\hline 紅班部 & 3 & $3.3 \mathrm{R}-7.1 \mathrm{R}$ & $5.47 \mathrm{R}$ & $(1.96)$ & $3.9-5.3$ & 4.47 & $(0.74)$ & $6.5-8.5$ & 7.43 & $(1.01)$ \\
\hline 頓粘膜扁平苔癬 & 10 & $3.5 \mathrm{R}-7.5 \mathrm{R}$ & $5.13 \mathrm{R}$ & $(1.27)$ & $3.5-6.3$ & 4.86 & $(0.92)$ & $5.1-8.4$ & 6.66 & (1.11) \\
\hline 白班部 & 2 & $6.0 \mathrm{R}-7.5 \mathrm{R}$ & $6.75 \mathrm{R}$ & $(1.06)$ & $5.8-6.3$ & 6.05 & $(0.35)$ & $5.1-6.0$ & 5.55 & $(0.64)$ \\
\hline 紅班部 & 8 & $3.5 \mathrm{R}-6.7 \mathrm{R}$ & $4.73 \mathrm{R}$ & $(0.99)$ & $3.5-5.4$ & 4.56 & $(0.75)$ & $5.3-8.4$ & 6.94 & $(1.04)$ \\
\hline
\end{tabular}

3.5〜6.3, 彩度は 3.6 8.5に分布していた。色相 の分布は，すべて $\mathrm{R} の$ 範囲に限られ，健常粘膜や 白板症に比べ狭かった。明度の分布は白板症に類 似していた。彩度の平均は白斑部は 4.90（SD： 0.87 ), 紅斑部は 6.85 (SD：1.02）であり, 白板 症に比べ高彩度のものが多かった。本研究にて測 色した粘膜疾患中, 扁平苔癬紅斑部の彩度の平均 は最も高かった（表 $10 ，$ 図 $8 \mathrm{a}$ )。

（2） $\mathrm{L}^{*} \mathrm{a}^{*} \mathrm{~b} *$ 表色系による扁平苔癬の色彩 扁平苔痽の明度 $\Delta \mathrm{L}^{*}$ は, 白斑部で 5 部位中 4 部
位が正の值を, 紅斑部で 14 部位中 11 部位が負の 値を示した。また色度 $\Delta \mathrm{a}^{*}, \Delta \mathrm{b}^{*}$ については, $\Delta$ b*が負の值を示し， $\Delta \mathrm{a}^{*}$ が正の值を示すものが 19 部位中 10 部位に認められた。このことは, $\Delta$ $\mathrm{a}^{*}, \Delta \mathrm{b}^{*}$ ともに負の值を示すものが多かった白板 症と異なっていた（図 $8 \mathrm{~b}$ )。

4 ）その他口腔粘膜疾患

色素沈着症 6 名（男性 1 名, 女性 5 名）の 8 部 位, 悪性黒色腫 2 名（女性 2 名）の 3 部位につい て測色を行った。 

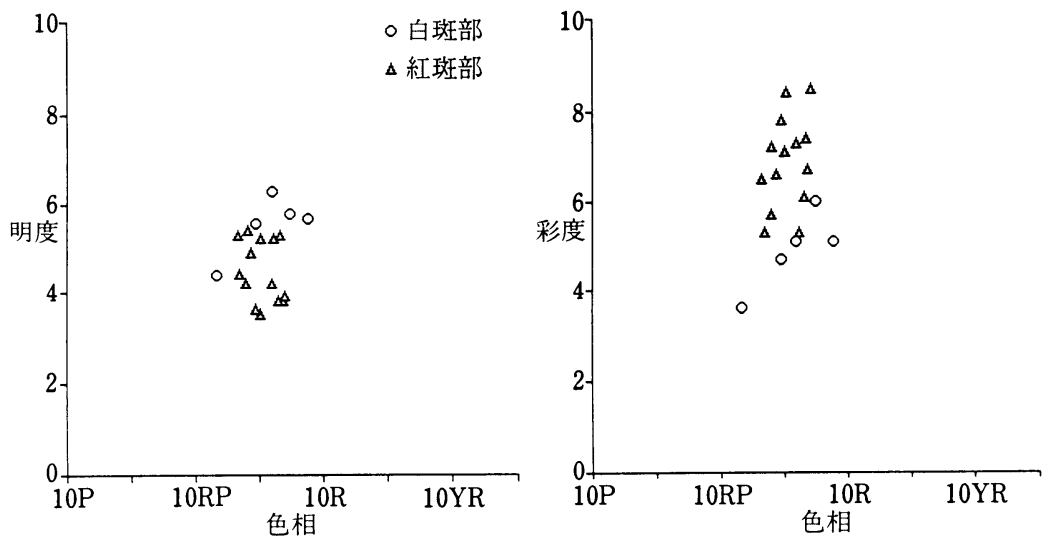

困 $8 \mathrm{a}$ 扁平苔癬の色彩分布 (マンセル表色系)
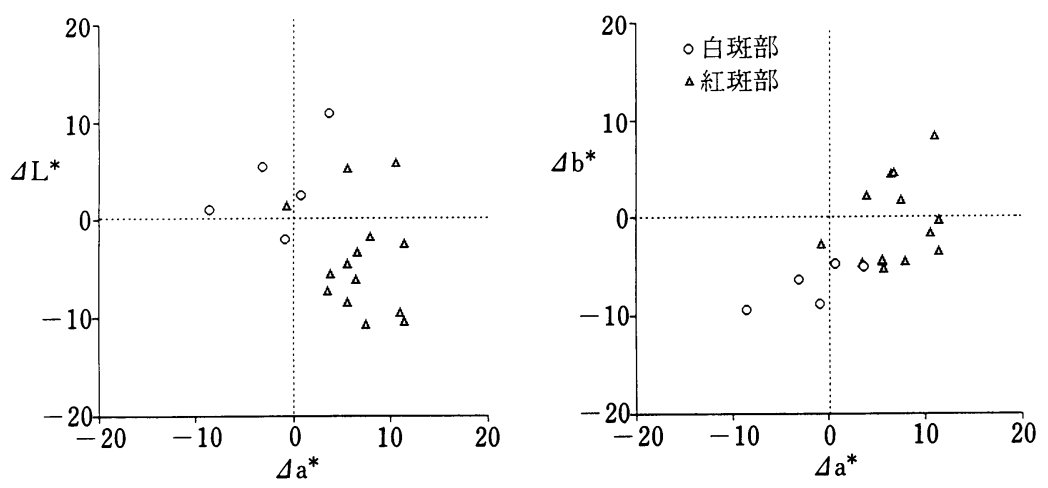

図 $8 b$ 扁平苔癬の色差分布 ( $\mathrm{L}^{*} \mathrm{a}^{*} \mathrm{~b}^{*}$ 表色系)

色素沈着症 は色相 $4.9 \mathrm{R} \sim 2.5 \mathrm{YR}$, 明度 3.2 4.9, 彩度 $0.8 \sim 4.0$ に分布していた。悪性黒 色腫については, 肉眼的に最も黒いと思われる部 位を測定したところ, 色相 $8.1 \mathrm{YR} \sim 4.3 \mathrm{Y}$, 明度 2.2 2.7, 彩度 $0.5 \sim 1.6$ であり, 色相は色素沈着 症と全く異なり, 明度は色素沈着症よりも低い傾 向であった。また, 悪性黒色腫は今回対象の口腔 粘膜疾患のなかで最も低明度, 低彩度に分布し, 色相は Y 方向に分布していた（表 11, 図 9）。

\section{IV. 考察}

\section{1. 表色系について}

色のみ之方は, 光源の分光分布, 試料の分光反 射率, 人間の目に対する分光感度で決まる。人間 には, 光源に対して 3 つの感度があり, これら 3
種各和の混合割合の変化によって色を認識すると いわれている9)。

人間の眼は，色と色を比較する能力は優れてい るが，色を記憶することは困難である。したがっ て色を正確に表現したり，伝達するためには，客 観的な色の表示が必要となる。色を表示する方法 には，色名による表示方法，三属性による表示方 法，測色值による表示方法などがある6)。

色名による表示方法は慣用色名, 系統色名があ る。臨床で，皮膚や粘膜の色を記載する場合，ほ とんどがこの表示方法を使用しているが，きわめ て大まかな表現しかできず，臨床写真などを併用 するのが通例となっている。

三属性 (HVC) による表示は, 色相 (Hue), 明 度 (Value), 彩度 (Chroma) という三要素にて表 
表 11 色素沈着症 6 例, 悪性黒色腫 2 例の色彩分布（マンセル表色系）

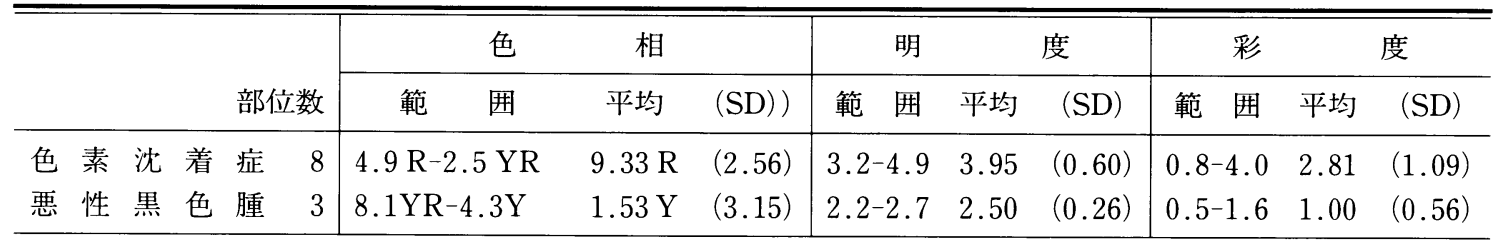
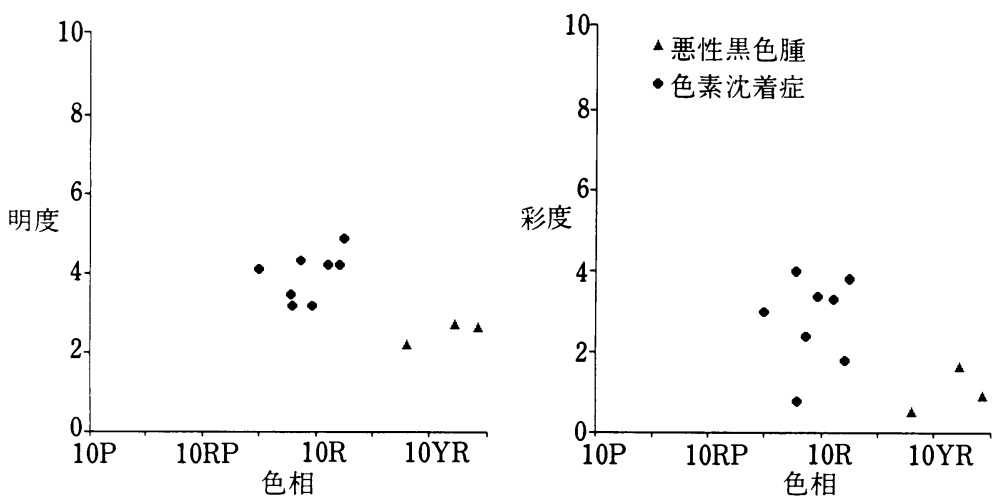

図9 色素沈着症, 悪性黒色腫の色彩分布（マンセル表色系）

現するもので，直感的に誰にでもわかりやすく， 值から色をイメージしやすいという利点がある。 通常，色票を使った視感比色法により表現され， 口腔粘膜色という狭い範囲の色系統内での微妙な 変化を捉えるためには，各要素の刻みを細分化す る必要があるが, 口腔粘膜用標準色票については すでに述べたとおりである3)。

測色値による表示は測色器の使用により可能に なるもので，代表的なものに国際照明委員会 (CIE) の定めた XYZ 表色系がある。この XYZ 表色系からは修正マンセル表色系, L*a*b*表色系 など他の表色系への変換が可能である。また等し い大きさに知覚される色差が, 空間内の等しい距 離に対応するように意図した色空間のことを均等 色空間という ${ }^{6}$ 。 L*a*b*表色系は CIEが 1976 年 に定めた均等色空間の一つであり，色差を表示す るときに多用される。口腔粘膜疾患の色彩を表現 するにあたり，この表色系を用いれば，健常粘膜 色からの色差として表示することが可能となる。

\section{2. 色彩の測定について}

色彩を測定する方法には, 視感比色法, 混合等 色法, 刺激值直読法, 分光測色法がある ${ }^{6)}$ 。視感比 色法と混合等色法は, 体系づけられた色のスケー ル（色票）と試料とを視感によって比較し，色彩 を測定する。正常な色覚をもった観測者が, 色彩 学的に管理された標準色票を用いて, 適切な光 源・照明のもとで比色操作を行わなければならな い。比色にあたり, 明度差・彩度差の違いを正し く判断することは難しい。色を比較し, 色の違い を正しく判断することや色の違いを表現できるよ うになるためには, 何度も繰り返し訓練する必要 性がある10)。

測色器を用いて測定される方法には, 刺激值直 読法と分光測色法があり, それぞれ色彩計, 分光 測色計が使用される6)。視覚を用いないため, より 客観的な色彩の計測が可能となる。

医学領域における色彩学的研究において, 医学 用標準皮膚色票を用いた皮膚色の研究は多いが, 粘膜色に関する研究は少ない。 
視感比色法による粘膜色の研究は, 鼻粘膜につ

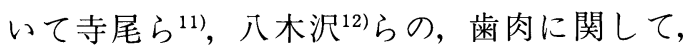
Ibusuki ${ }^{13,14)}$, 浅岡 ${ }^{15)}$ らの報告がある。藤井は 485 色の口腔粘膜疾患診断用標準色票 (口腔粘膜比色 スケール)を試作し，健常口腔粘膜，口腔白板症， 口腔粘膜癌について, 視感比色法を行い報告して いる ${ }^{3)}$ 。歯周疾患, 鼻粘膜炎などの炎症性病変の色 彩学的変化は, 比較的限られた色調内の変化が主 であるのに比べ，口腔白板症や口腔粘膜癌は，多 様な色彩変化を示す。一方, 同病変中にはきわめ て微妙な変化を示すものもある。このように多様 な色彩変化と微妙な粘膜色の違いを正確に表現す るには，より細分割した色票が必要だが，色票の 数が多くなると, 操作が煩雑になり, 色票の選択 がきわめて困難となる。

測色器を用いた口腔粘膜色の研究は, 古くは, 石川 ${ }^{16)}$ が歯肉色測定器を試作し測定を試みてい る。また金子 ${ }^{17)}$ は微少面色彩計を作製し, 平塚 ${ }^{18)}$, 等々力 ${ }^{19}$ らはさらにこれを改良し健常歯肉, 歯周 疾患の測色を行い報告している。しかし，いずれ の結果も, 視感比色值とかけ離れた測色結果とな ク, 科学的には満足のいくものではなかった。近 年, あらゆる分野で色彩管理の需要が高まるとと もに, 光学技術, 光計測技術およびエレクトロニ クス技術の進歩により, 信頼性が高く, 高精度で, さまざまなタイプの色彩計が登場してきた。分光 測色計は高精度で絶対值測定が可能であるが，現 存のものは色彩計に比べ大型であり口腔内への適 応は困難である。本研究では, 測定部が小型で, 口腔内への適応の可能性のみられた，2種の色彩 計を検討することとした。

接触型色彩計は測定に際して，ファイバー先端 部を被検部に密着させ, 遮光するため, 測定条件 を一定に保つことが容易である。しかし，被検部 が平坦でない場合, 密着させることが困難であり, また口腔内の測定の場合ファイバー部の消毒とい う衛生上の問題がある。一方, 非接触型色彩計は, 被検部から離れて測定を行うため, 衛生上の問題 はないが，測定条件を一定に保つことが重要であ る。そこで, 健常者の歯肉, 舌側縁について測色
を行い比較したところ，接触型色彩計の測定值は 視感比色值とかけ離れていた。粘膜色は表面色で はなく, 皮下の血液, 脂肪などの組織が, 上皮と いうべールを通して表現された半透過色といえ $3^{20)}$ 。接触型色彩計では, 測定時ファイバー先端部 を被検部に密着させることが必要であるが，たと えフェザータッチでも，この操作により圧が加わ ク, 上皮下の血流動態に変動を起こす可能性があ る。また，ファイバー部より供給される光源が， 逆に上皮を通して乱反射を起こすことにより，視 感比色值, 肉眼所見とはかけ離れた值を示してい た。特に彩度は著しく低い值を示し，これまで報 告されている, 同夕イプの色彩計を用いた, 粘膜 色の測定結果にも同様の傾向が認められ た ${ }^{17 \sim 19)}$ 。

一方, 非接触型色彩計の測定值は歯肉, 舌側縁 ともに視感比色值に近似し, 肉眼所見と一致して いた。非接触型色彩計では, 被検部に触れずに測 定するため, 粘膜下の動態に影響を与えることな く測定できることからも, 口腔粘膜色の測定には 非接触型色彩計が適していると判断された。

本色彩計による測定条件について検討したとこ ろ, 室内照明, デンタルライト下での測定值は, 黄色味がかった色相を示し, 測定值の変動も大き かった。しかし標準光源を用いた場合, 室内照明 の有無, 光源の距離, 測定距離による影響は少な く, 一定した值が得られた。

測定に先立ち, 通常は標準白色板 (ミノル夕製) を用いて任意基準校正を行い, 測定時の条件を一 定としているが, この標準白色板は大きくてロ腔 内に挿入できないため，口腔内に扱入できるよう な, 小型のデンタルミラー型標準白色板を試作し, 任意基準校正を行うことにした。このようにして 健常者の下唇, 歯肉, 舌側縁, 顂粘膜などを測定 したところ, 精度・再現性ともに優れており，以 下, この方法に従って口腔粘膜の色彩を計測する こととした。

\section{3. 健常口腔粘膜の色彩について}

色彩色差計を用いて測定した健常口腔粘膜の色 彩は, 色相 $5.0 \mathrm{R} \sim 4.1 \mathrm{YR}$, 明度 $3.5 \sim 6.0$, 彩度 
表 12 色彩色差計と視感比色法による健常者口腔粘膜色彩の比較

\begin{tabular}{|c|c|c|c|c|c|c|c|c|}
\hline 測定方法 & $\begin{array}{r}\text { 下 } \\
\text { 色相 } \\
\end{array}$ & $\begin{array}{c}\text { 唇 } \\
\text { 明度/彩度 }\end{array}$ & $\begin{array}{l}\text { 歯 } \\
\text { 色相 } \\
\end{array}$ & $\begin{array}{c}\text { 肉 } \\
\text { 明度/彩度 }\end{array}$ & $\begin{array}{r}\text { 舌 } \\
\text { 色相 } \\
\end{array}$ & $\begin{array}{c}\text { 縁 } \\
\text { 明度/彩度 }\end{array}$ & $\begin{array}{r}\text { 煩 } \\
\text { 色相 } \\
\end{array}$ & $\begin{array}{l}\text { 膜 } \\
\text { 明度/彩度 }\end{array}$ \\
\hline $\begin{array}{l}\text { 色彩色差計 } \\
\text { (平 均 値) }\end{array}$ & $9.77 \mathrm{R}$ & $4.42 / 4.75$ & $1.27 \mathrm{YR}$ & $4.82 / 4.98$ & $7.99 \mathrm{R}$ & $4.56 / 5.18$ & $0.30 \mathrm{YR}$ & $5.42 / 5.76$ \\
\hline $\begin{array}{l}\text { 視感比色法* } \\
\text { (最 頻 值) }\end{array}$ & $10 \mathrm{R}$ & $4.0 / 4.0$ & $2.5 \mathrm{YR}$ & $5.0 / 4.0$ & $7.5 \mathrm{R}$ & $4.0 / 4.0$ & $10 \mathrm{R}$ & $5.0 / 4.0$ \\
\hline
\end{tabular}

*藤井 $(1985)^{3)}$

$3.7 \sim 6.7$ に分布していた。部位別に比較すると, 色相については下唇・頪粘膜に比べ舌側縁は RP 方向に，歯肉はYR 方向に分布していた。また明 度・彩度については, 頓粘膜が他に比べ高明度・ 高彩度であった。藤井の視感比色法を用いた健常 者口腔粘膜の色彩 ${ }^{3)}$ と, 色彩色差計を用いた本研 究結果を比較すると，色相・明度は，各部位でき わめて近似するものであったが, 彩度は色彩色差 計のほうが視感比色法に比べ, やや高值を示した

(表 12)。なお, 本研究結果は平均値で, 藤井は最 頻值で示しているため, 詳細な比較は困難である。 また，今回の測定結果においては，明らかな男女 差および年齢差はみられなかったが，さらに例数 を増やし検討を加える必要があると考えられた。

\section{4. 口腔粘膜疾患の色彩について}

\section{1) 白板症}

白板症の肉眼的特徵および診断において色彩の 判断は重要である。色彩色差計を用いた測色の結 果, 白板症の色彩は, 健常粘膜に比べ色相, 明度, 彩度ともに広い範囲に分布していた。色相につい て白斑部と紅斑部を比較すると，白斑部が広範囲 に分布していたのに対し，紅斑部の色相分布は $5.0 \mathrm{R} \sim 7.0 \mathrm{R}$ と狭い範囲に限られていた。また白 斑型のなかでも, 舌白板症は RP 方向, 歯肉白板症 はYR 方向，と健常粘膜色を反映した分布傾向を 示し, 白斑部では, 基盤となっている色彩が, 健 常粘膜のものと同様であると推測される。この上 に，上皮の角化・肥厚・凹凸といった変化が加わ ることにより，健常粘膜より広範囲な色相分布を 示すと考之られた。逆に, 紅斑部では, 上皮が薄 くなるほど，その色彩は上皮下の血液色に近づく
ため色相の変化が少ないものと考えられた。本研 究結果を, 藤井の視感比色法を用いた白板症の色 彩 ${ }^{3)}$ と比較すると，色相および紅斑部の明度・彩度 については視感比色の結果と一致していたが, 白 斑部については視感比色に比べ低明度・高彩度の ものも多くみられた。肉眼的に病変部が白くみえ るか, 赤くみえるかは, 周囲の健常粘膜色との比 較において決定される。周囲粘膜色に比べ高明度, あるいは低彩度であれば肉眼的に白くみえ, 高彩 度であれば赤くみえる。そこで病変部の色彩が健 常粘膜と比較して，色彩学的にどのような位置関 係にあるのかを知るために, $\mathrm{L}^{*} \mathrm{a}^{*} \mathrm{~b}^{*}$ 表色系を用い て検討した。

白板症の色彩を同一者の健常粘膜からの色差と して L*a*b*表色系を用いて表すと，明度を表す $\Delta \mathrm{L}^{*}$ は白斑型で正の值を, 紅斑型で負の值を示す ものが多かった。しかし，逆に白斑型で負の值を， 紅斑型で正の值を示すものも少数例に認められ た。これらは病変の湿潤や，起伏・凹凸などによ ク生じたものと考えられる。なお，凹凸を有する 病変の色のむらを減じるために，複数の光源を多 方向から照明するなどの工夫も, 今後の検討課題 といえよう。色度 $\Delta \mathrm{a}^{*}$ と $\Delta \mathrm{b}^{*}$ は正の相関を示す 傾向にあり, 白斑部では $\Delta \mathrm{a}^{*}, \Delta \mathrm{b}^{*}$ ともに負の值 を，紅斑部では正の值を示すものが多かった。こ のことから白板症の色彩は, 健常粘膜色を基調と し, 主として色味の増減により白斑・紅斑を生じ る, すなわち色味が薄いものは白斑, 色味が濃い ものは紅斑として表現されると考えられた。

白板症の上皮性異形成は悪性潜在能を知るうえ で重要であるが、上皮性異形性と臨床像との関係 
について，びらんや紅斑を伴ったものに上皮性異 形成の頻度が高いとされている。天笠らは、白斑 型に比へ， 紅斑混在型に多く上皮性異形性を認め たとしている ${ }^{21)}$ 。藤井は彩度 8 以上のものは上皮 性異型性中等度であったと報告しており3)，本研 究からは，白板症の上皮性異形成が高度になるに 従って，彩度が高くなる傾向がみられた。以上よ $\eta$, 色彩色差計を用いることにより, 視感比色法 よりもさらに精度が高く, 客観的な色の評価が可 能であり，白板症の悪性潜在能の診断に有用であ ると考えられた。

\section{2）扁平上皮癌}

扁平上皮癌の色相分布は白板症に比べ狭い範囲 に限られており, 進行癌, 早期癌に分けて比較す ると, 早期癌では進行癌よりさらに分布範囲が狭 かった。彩度については白板症にみられた低彩度 は認められず，扁平苔癬にみられた高彩度は認め られなかった。また色差分布をみると, 明度 $\Delta \mathrm{L}^{*}$ は白板症よりもばらついており, 白色部でム $\mathrm{L}^{*} か ゙$ 負の值を示し, 赤色部で $\Delta \mathrm{L}^{*}$ が正の值を示すもの が多くみられた。このことは扁平上皮癌において は，表面の起伏，凹凸がさらに強くなるため，光 源光の反射がさらに増大するためと考えられた。 色度 $\Delta \mathrm{a}^{*}, \Delta \mathrm{b}^{*}$ の分布は, 進行癌では, 特徵がみ られなかったが，早期癌では $\Delta \mathrm{a}^{*}$ が正の值を， b*が負の值を示すものが多かった。このことから 早期癌では, 赤方向で, やや色味の濃い色が多い と考えられた。

以上より, 癌の臨床像は, 一見多彩にみえるが, 形態的多様さ，色彩の不均一さによるものであり， 色彩的な変化には乏しいと考えられた。また癌の 色彩が不均一であることを考えると，今後病変全 体における色の分布を詳細に検討寸る必要がある と考えられた。

\section{3 ) 扁平苔癬}

扁平苔痖の中には，白斑やびらんを主としたも のもあり，時として白板症や早期癌との鑑別が困 難なことがある。本研究結果からは扁平苔鹰の色 相の分布は狭く, 今回測定した口腔粘膜疾患のな かでは最も高彩度であった。このことは，白板症
や癌との違いの一つといえよう。また $\mathrm{L}^{*} \mathrm{a}^{*} \mathrm{~b}^{*}$ 表 色系の色差分布からは，扁平苔癬は白板症と異な ることが示されており，診断の一助になりうるこ とが示唆された。

4）その他口腔粘膜疾患

悪性黒色腫は，覀性度が高く，生検診断は極力 避けるべきとされているが, 他の色素性病変との 鑑別が困難なことも少なくない22)。今回, 色素沈着 症と悪性黒色腫の色彩を測定，比較したところ, 悪性黒色腫では，色素沈着症よりさらに低明度で あり，色相は他のいずれの疾患にもみられない $\mathrm{Y}$ 方向に位置しており，両者の色彩分布に差が認め られた。このことは, 悪性黒色腫の診断において は非常に有用で，侵襲を加えない色彩学的な鑑別 診断の可能性を示唆するものと考えられた。

\section{VI. 結 論}

口腔粘膜疾患の色彩を客観的，定量的に評価し 診断に応用するために，色彩計による計測を試み た。ついで健常口腔粘膜および口腔粘膜疾患の色 彩を測定し，以下の結果を得た。

1. 接触型色彩計および非接触型色彩計を用い て, 口腔粘膜の測色方法について検討したところ， 接触型色彩計は視感比色值とかけ離れていたのに 対し, 非接触型色彩計は視感比色法の結果に近似 していた。

2. 色彩色差計 CS-100の測定方法について検 討したところ，標準光源を用い，試作したデンタ ルミラー型白色板にて任意基準校正を行うことに より，口腔粘膜の測色精度，再現性ともに優れて いた。

3. 健常口腔粘膜の色彩は色相 $5.0 \mathrm{R} \sim 4.1$ $\mathrm{YR}$, 明度 3.5 6.0, 彩度 3.7 6.7 に分布してい た。各部位を比較すると舌側縁の色相は $\mathrm{R}$ 方向に 分布したのに対し，歯肉は YR 方向に分布してい た。煩粘膜の明度および彩度は他に比べ高かった。 また，これら所見は視感比色法の結果と一致する ものであった。

4. 白板症の色相は $2.6 \mathrm{RP} \sim 3.4 \mathrm{Y}$, 明度は $3.7 \sim 7.0$, 彩度は $0.3 \sim 8.3$ に分布していた。白板 
症の色相分布は, 白斑部は広範囲であったが, 紅 斑部は $5.0 \mathrm{R} \sim 7.0 \mathrm{R}$ と狭かった。白斑部の明度は 紅斑部, 健常粘膜に比べやや高かった。彩度につ いては白斑部では 3.0 以下の低彩度, 紅斑部では 7.0 以上の高彩度の色まで認められた。

上皮性異形性と色彩との関連を舌白板症に限っ て検討したところ，上皮性異形成が高度になるに 従って, 彩度が高くなる傾向がみられ, 色彩によ $\eta$, 上皮性異形成の程度を診断する一助になる可 能性が示唆された。

5. 進行癌の色相は $3.0 \mathrm{R} \sim 8.2 \mathrm{YR}$, 明度は 2.7〜6.4, 彩度は 3.0 7.8に分布していた。また 早期癌の色相は $4.2 \mathrm{R} \sim 8.3 \mathrm{R}$, 明度は $4.2 \sim 6.0$, 彩度は3.9 6.5に分布していた。色相の分布範囲 は白板症に比べ狭く, 早期癌は進行癌よりさらに 狭かった。癌の彩度は白板症にみられた低彩度, 扁平苔癄にみられた高彩度は認められず，色彩変 化に乏しかった。

6. 扁平苔癬の色相は $1.7 \mathrm{R} \sim 8.9 \mathrm{R}$, 明度は 3.5 6.3, 彩度は 3.6 8.5に分布していた。色相 の分布は, $\mathrm{R} の$ 範囲に限られ, 明度の分布は白板 症に類似していたが, 紅斑部の彩度は, 本研究に て測色した粘膜疾患のなかで最も高かった。

7. 色素沈着症は色相 $4.9 \mathrm{R} \sim 2.5 \mathrm{YR}$, 明度 3.2〜 4.9, 彩度 $0.8 \sim 4.0$ に分布していた。悪性黒 色腫の色彩は色相 $8.1 \mathrm{YR} \sim 4.3 \mathrm{Y}$, 明度 2.2〜2.7, 彩度 0.5 1.6であった。両者とも他の 粘膜疾患に比べ明度・彩度ともに低かったが, 悪 性黒色腫は, 今回の対象症例中, 最も低明度であ ク, 色相は他の疾患にみられない $\mathrm{Y}$ 方向に分布し ていた。

以上より, 色彩色差計による口腔粘膜疾患の色 彩測定は, 個々の病変の比較, 経時的変化の記録 に有用であり，これら色彩の評価は口腔粘膜疾患 の診断の可能性を示唆するものと考えられた。

\section{謝辞}

稿を終えるに臨み，ご贸切なる指導とご校閲を賜り ました天笠光雄教授に謹んで感謝の意を表します。ま た, ご校閲戴きました本学歯科理工学第 1 講座の
西村文夫教授に感謝申し上げます。さらに終始愳切な るご指導とご教示をいただきました本学口腔外科学 第 1 講座の藤井英治先生に心からお礼申し上げます。 また本研究に, ご援助, ご協力をいただきました力 ラーランド元吞昭夫氏, 本学口腔外科学第 1 講座の諸 先生に心からお礼申し上げます。

なお, 本研究の一部は第 36 回日本口腔外科学会総 会(1991 年 10 月 1 日, 大阪), 第 47 回日本口腔科学会 総会 (1993 年 2 月 23 日, 弘前), 第 58 回口腔病学会学 術大会 (1993 年 11 月 27 日, 東京), 第 18 回日本頭頸 部腫瘍学会 (1994 年 6 月 23 日, 札幌)において発表し た。

本研究の一部は昭和 63 年 平成 2 年度文部省科学 研究費補助金（一般 C) No.63570930によった。

\section{文献}

1）天笠光雄, 戸塚盛雄, 増尾勝已, 永井譲次, 清水 正嗣, 塩田重利, 道 健一, 斉藤健一: 口腔白板 症の臨床型, 治療法と予後に関する研究一特に白 板症の悪性化について一. 日口外誌 24 ： 243-251, 1978.

2) 天笠光雄：口腔粘膜早期扁平上皮癌の初期症状 と診断について。回病誌 $59: 301-306,1992$.

3）藤井英治：口腔白板症および粘膜癌の色彩学的 研究. 口病誌 $53: 208-231,1986$.

4）法水正文：医学における色彩の観察記録と光電 色彩計の発達. 日本医事新報 $2827: 22-27$, 1979.

5）千々岩英彰：色彩学. 東京， 1985, 福村出版, 52-75.

6）平井敏夫：色をはかる. 東京, 1989 , 日本規格協 会.

7) WHO collaborating centre for oral precancerous lesions: Definition of leukoplakia and related lesion ; an aid to studies on oral precancer. Oral Surg. $46: 518-539,1978$.

8）天笠光雄, 横尾美恵子, 結城勝彦, 岩城 博, 立 花忠夫, 藤井英治, 塩田重利：口腔粘膜早期浸潤 癌の臨床的研究. 日口外誌 $26: 1497-1507$, 1980.

9）川上元郎：新版 色の常識. 東京, 1987, 日本規格 協会.

10）片山伊九右衛門，鬼島成和：色合わせの訓練法. 日本歯科色彩研究会, 歯科色彩の話 東京, 1993, クインテッセンス出版, 80-90.

11）寺尾 彬, 佐藤靖雄; 鼻粘膜の色彩に関する研 究. 日耳鼻 $78: 501-507,1975$.

12）八木沢幹夫：鼻粘膜の色彩学的研究一特に下鼻 甲介の観察一. 耳展 補 3:164-179, 1977. 
13) Ibusuki, M. : The color of gingiva studied by visual color macthing. Part I. Experimental studies on the discriminatin threshold for color difference and effectof training. Bull. Tokyo Med. Dent. Univ. 22 : 249-261, 1975.

14) Ibusuki, M. : The color of gingiva studied by visual color macthing. Part II. Kind, location, and personal difference in color of gingiva. Bull. Tokyo Med. Dent. Univ. 22 : 281-292, 1975.

15）浅岡一馬：炎症性歯肉の色彩に関する研究一視 感比色法による測色結果について一. 補緅誌 $22: 664-678,1978$.

16）石川信昭：歯肉色測定法に関する研究。口病誌 $25: 611-621,1958$.

17）金子利一郎：ヒトの歯肉に関する色彩学的研究. 日大歯学 $42: 570-578,1968$.
18）平塚鉄也：歯肉色と歯肉毛細血管像との関連に ついて. 日歯周誌 $13: 49-58,1971$.

19）等々力正勝：新微小面色彩計による歯周病歯肉 色の測定. 日歯周誌 $13: 59-67,1971$.

20）法水正文, 武藤次郎, 坊野馨二, 西山明雄: 鼻甲 介, 口唇粘膜色の光電色彩計他による測定成績. 日耳鼻 $86 ： 295-303 ， 1983$.

21）天笠光雄, 增尾勝己, 藤井英治, 道 健一, 斉藤 健一：口腔白板症の臨床的病理組織学的研究 一特に臨床型と病理組織学的所見との関連につ いて一. 口病誌 $46: 30-42,1979$.

22) Tanaka, N., Amagasa, T., Iwaki, H., Shioda, S., Takeda, M., Ohasi, K., Reck, F. S. : Oral malignant melanoma in Japan. Oral Surg. Oral Med. Oral Pathol. 78 : 81-90, 1994. 